\title{
Kişilik Tipi İle Kariyer ve Akademik Desteğin Kariyer Uyum Yeteneklerine Etkisi: Bir Saha Araştırması
}

DOI: $10.26466 /$ opus.586662

\begin{abstract}
Mehmet Ali Taš - Mehmet Özmen**
* Arş. Gör, Burdur Mehmet Akif Ersoy Üni., İ.İ.B.F., Sağlık Yönetimi Bölümü, Burdur/Türkiye E-Posta: matas@mehmetakif.edu.tr ORCID: 0000-0001-9714-7188

** Dr. Öğr. Üyesi, Burdur Mehmet Akif Ersoy Üniversitesi, Bucak Zeliha Tolunay Uygulamalı Teknoloji ve İşletmecilik Yüksekokulu, Yönetim Bilişim Sistemleri Bölümü, Burdur/Türkiye E-Posta: mehmetozmen@mehmetakif.edu.tr

ORCID: 0000-0001-6369-8686
\end{abstract}

Öz

Henüz çalışma hayatına atılmamış bireylerin iş dünyasında meydana gelen değişimlere hazırlıklı olması gerekmektedir. Bu noktada, bireylerin zihinsel ve duygusal yapıdan oluşan kariyer uyum yetenekleri önemli bir rol oynamaktadır. Bu yapının geliştirilmesi, güçlendirilmesi mümkündür ve başka faktörlerden etkilenmesi de muhtemeldir. Buradan hareketle yapılan bu çalışmada A ve B kişilik tipleri ile kariyer ve akademik desteğin kariyer uyum yetenekleri üzerindeki etkisi araştırılmıştır. Burdur Mehmet Akif Ersoy üniversitesinin İ.I.B.F 4. Sınffve Sosyal Bilimler Enstitüsünün lisansüstü eğitimine devam eden toplam 499 kişi üzerinde anket yöntemi kullanılarak bir araştırma yapılmıştır. Elde edilen bulgulara göre A ve B kişilik tipleri ile kariyer ve akademik desteğin kariyer uyum yetenekleri üzerinde anlamlı ve olumlu bir etkisinin olduğu tespit edilmiştir. Ayrıca A kişilik tipinin yarattığı etkinin, B kişilik tipinin etkisine kıyasla daha yüksek olduğu tespit edilmiştir. Boyutlar bağlamında ise A kişilik tipi en yüksek kontrol boyutunu, B kişilik tipi de ilgi boyutunu etkilemektedir. Bunun yanında ayrica kariyer ve akademik desteğinin de en fazla ilgi boyutunu etkilediği saptanmıştır.

Anahtar Kelimeler: Kişilik, A ve B Kişilik Tipleri, Kariyer ve Akademik Destek, Kariyer Uyum Yetenekleri 


\title{
The Effect of Personality Type and Career and Academic Support on Career Adaptability: A Field Research
}

\begin{abstract}
Individuals who have not yet been put into working life should be prepared for the changes occurring in the business world. At this point, individuals' mentally and emotionally structured career adaptability skills play an important role. It is possible to develop, strengthen and be influenced by other factors. In this study, the effects of $A$ and B personality structure and career and academic support on career adaptability were investigated. For this purpose, a total of 499 person attending the graduate program of the Institute of Social Sciences and Faculty of Economics and Administrative Sciences of Burdur Mehmet Akif Ersoy university have been conducted by using the survey method. According to the findings, the personality typeof $A$ and $B$, career and academic support have a significant and positive effect on career adaptability. However, the effect of personality type $A$ was found to be higher than the effect of type $B$ personality. In the context of dimensions, type A personality affects the most control factor. B personality type and career and academic support were also found to affect the factor of concern most.
\end{abstract}

Keywords: Personality, Type A and Type B Personality, Career and Academic Support, Career Adaptability 


\section{Giriş}

Günümüzde yaşanan hızlı gelişmeler ve sürekli değişen çevre şartları, insanların iş hayatında daha hızlı meslek değiştirmesine sebep olmaktadır. Nitekim günümüzde çalışanların bir dizi bilgi, beceri ve yetkinlik kazanması konusunda örgütlerin daha fazla beklentiye girmektedir. Diğer taraftan bireyler; teknolojiye ayak uydurma, esnek olabilme ve kendi istihdam olanaklarını yaratma noktasında çaba göstermek durumundadır. $\mathrm{Bu}$ açıdan bakıldığında bireylerin kariyer gelişimi kuruluşa bağlı değil, kişinin kendisinin belirlemesi gerektiği ileri görülmektedir (Potgieter, 2014, s.20-22). Bireylerin karşılaştığı bu teknolojik ve iş hayatındaki kapsamlı değişim; farklılıklara uyum gösterme kabiliyetini, iş hayatının beklentilerini ve bunun yanında kendilerini geliştirmelerini vurgulamaktadır (Barutçu, 2004, s.319; Güney, 2014, s.145). Yani bu değişimler kişileri birden fazla yeteneğe sahip olmaya doğru itmektedir. Bireylerin kendilerini çevresel koşullara göre revize etme ihtiyacını doğurmaktadır (Karacan ve Güneri, 2017, s.196).

Çevresel faktörlerin yanında kariyer seçimi üzerinde en fazla etkisi bulunan unsurlardan bir tanesi de şüphesiz zaman içerisinde az değişim gösteren kişilik özelliğidir (Onay ve Zel, 2011, s.266). Kişilik unsuru hayatın her aşamasında kendini gösteren ve alınan kararlarda etkili olan önemli bir faktördür. Tercih edilen meslek ile kişilik yapısının uyumlu olması gerekmektedir. Meslek/iş, kişinin ihtiyaç ve değerlerini karşılarsa ve bu işi yaparken işin gerektirdiği yetenek ve beceriler o kişide mevcut ise kişi ile iş arasında uyum gelişmektedir. Yüksek performansın sağlanabilmesi için işin gerektirdiği yetenekler (çevresel faktörler) ile bireyin yetenekleri (kişisel özellikler) denk olması gerektiği konusunda bir mutabakat mevcuttur (Ünsal, 2014, s.149-150). Bu nedenle bireysel farklılıklara odaklanmak ve kariyer planını bu doğrultuda hazırlamak bireyin iş hayatındaki başarısını, iş ve yaşam doyumunu büyük ölçüde etkileyeceği düşünülmektedir. Dolayısıyla hangi mesleğin hangi yetenek ve becerileri gerektirdiğini ölçmek ve belirlemek önem kazanmaktadır (Swanson ve Schneider, 2013; Dawis, 2005; Akt. Ünsal, 2014, s.158).

Super (1992), 18-21 yaş aralığındaki genç bireylerin iş hayatına yeni atılacağ 1 dönem olduğunu ifade etmektedir. Kariyerin orta yaş aşaması ola- 
rak da bilinen bu dönem, kariyerin zor aşamalarını içermektedir. Bu aşamadaki bireylerin kariyere ilişkin düşünceleri daha gerçekçi olduğu ifade edilmektedir. Ki bu dönemde ayrıca endişeler de artmaktadır. Türkiye'de genç bireyler mezun olamaya yakın uygun bir işe yerleşme kaygısı ortaya çıkmaktadır. Özellikle son yıllarda artan mezun sayısı ve bu bağlamda oluşan işgücü arz fazlası bu kaygıyı gittikçe arttırmaktadır (Zorver ve Korkut-Owen, 2011, s.326).

Üniversite mezunları, genel olarak ya mezuniyete az kalınca ya da mezun olduktan hemen sonra iş aramaktadır. Bu durum da zor bir süreci kapsamaktadır. Genellikle kişisel özelliklerini değerlendirmek, iş piyasası bilgilerini aramak, başvuruları göndermek, mülakatlara katılmak, potansiyel işverenlerle görüşmek gibi sabır gerektiren bir dizi aşamalardan geçmektedir (Wanberg, Zhang and Diehn, 2010). Üniversite mezunları bu tür aşamalarla yeni tanıştığından dolayı iş arama eylemi genellikle stresli ve beklenmedik zorluklarla dolu olmaktadır (Turban, Stevens and Lee, 2009). Kariyer uyum yeteneklerinin, üniversite mezunlarının iş aramada kendi kendini düzenleme kapasitesini ve bu nedenle istihdam olasılı̆̆ını arttıracağı ileri sürülmektedir (Guan vd., 2013, s.562). Bunun yanında çalışmaya başlayan bireyler örgüte faydalı olmak, örgütün başarılarında ve gelişmesinde rol almak konusunda hevesli olmaktadır. Ancak birey-örgüt çıkarları arasında çelişkilerin yaşanması sonucunda hayal kırıklığı yaşanabilmektedir. Temel sebebin ise işe başlamadan önce iş hakkında yeterince araştırma yapılmaması olarak ifade edilmektedir. Bu durum, çalışanın ve örgüttün birbirinden gerçek dişı beklentileri olarak tabir edilen "Kariyer Şoku" sendromuna sebep olmaktadır (Barutçugil, 2004, s.327; Güney, 2014, s.148; Bingöl, 2013, s.335; Ertürk, 2011, s.212).

Kültürel yapı gereği Türk toplumu için garanti mesleği tercih etme eğilimi yüksek düzeydedir. Çünkü belirsizliğe toleransı ve risk alma düzeyi düşüktür. Fakat günümüzde proje temelli işler ve mobil çalışana ihtiyaçlar gitgide artmaktadır. Yavaş da olsa toplumun da buna ayak uydurması gerekmektedir. Bu bağlamda bireylerin kişilik özelliklerini göz önünde bulundurarak kariyer planlarını yeniden gözden geçirmesi, akademik danışmanlarından destek alması ve kariyer uyum yeteneklerini geliştirmesi önem kazandığ1 görülmektedir (Karacan ve Güneri, 2017, s.196). 
$\mathrm{Bu}$ çalışmada, eğitim hayatının sonuna gelmiş, iş hayatına atılmak üzere olan 4. Sınıf ve lisansüstü öğrencilerinin kariyer uyum yeteneklerinin düzeyini belirlemeye ve kişilik tipleri ile kariyer ve akademik desteğin kariyer uyum yetenekleri üzerindeki etkisi ortaya konulmaya çalışılmıştır. Diğer yandan bu örneklem kitlesinin lisans yönünü oluşturan kitlenin tamamı 4. Sınıf öğrencileri olması nedeniyle birçok akademik danışmanla karşılaşmış olmaları ve bunlardan danışmanlık tavsiyeleri veya rehberlik almış olmaları beklenmektedir.

\section{A ve B Kişilik Tipleri}

Kişilik kavramının kökeni "personality" kelimesinden gelmektedir. Bu kavram Latince'de bir tiyatro maskesi olan "persona" kelimesine dayanmaktadır. Bu bağlamda kişilik bir bireyin toplum içerisinde oynadığı rol olarak ifade edilebilir. Allport'ın (1961) ifadesiyle kişilik doğuştan ve sonradan kazanılan yetenekler bütünü ve çevreye uyumudur. Kişilik bir yaşam tarzıdır. Tutarlı davranış kalıplarıdır. Bireyi farklı kılan özellikler, inançlar ve davranışların yansımasıdır (Güney, 2018, s.184). Bireyin özgün nitelikleridir (Özkalp, 2015, s.29). Kişilik bir insanı diğerlerinden ayıran ya da onlarla olan benzerliğini ortaya koyan niteliklerin tümüdür (McShane ve Von Glinow, 2016, s.29). Kişilik, bireyin psikolojik sisteminin gelişmesini ortaya koyan dinamik bir filmdir (Robbins ve Judge, 2015, s.134). Aktif ve süreçleri olan bir olgudur (Çetin ve Basım, 2014, s.98).

İnsanların biyolojik yapıları benzerlik gösterse de benzer bir olaya olan tepkileri, tutum ve davranışları farklılık göstermektedir (Özkalp, 2015, s.29). Ancak bunlardan belirgin şekilde ayırt edilebilen davranış kalıpları kişilik özelliği olarak ifade edilmektedir. Bu davranış kalıpları sayesinde bireysel farklılıkları ortaya konulmakta ve etiketlenmektedir. Ayrıca bunlara bakarak bireylerin nasıl davranacakları da kestirilmektedir (Şimşek, Çelik and Akgemci, 2016, s.81; McShane ve Von Glinow, 2016, s.30).

A tipi ve B tipi kişilik yapısı ilk olarak 1955-1958 yılları arasında iki kardiyolog olan Meyer Friedman ve Rosenman tarafından ortaya konulmuştur. Bu kişilik yapısının ortaya atılması koroner kalp hastalarına ilişkin risk faktörlerinin araştırıldığı çalışmalara dayanmaktadır. Bu çalış- 
mada A tipi hastaların sergiledikleri davranışların koroner kalp hastal1ğını 2 kat arttırdığı bulgularından yola çıkılarak keşfedilmiştir (Friedman ve Rosenman, 1959, s. 1286-1298; McKenna, 2010, s. 34).

A tipi kişilik özelliklerine sahip bir kişi birçok açıdan yüksek beklentiye sahip olduğu görülmektedir. Bu beklentilere ulaşabilmek adına çeşitli alternatif yolları aramaktadır. Başarı elde ettiklerinde kısa süreli hedonik bir mutluluk elde etmektedir. Zaman baskısını ciddi şekilde hissetmektedir. Hem kendileriyle hem de zamanla yarışmaktadır. Rekabet onlar için önemli bir motivasyon kaynağıdır. Risk alma düzeyleri yüksek hatta çevrede bulunan diğer herkesle rekabet etme hissine kapılmaktadırlar. Aşırı düzeydeki bu rekabet duygusu yoğun stresi ve kaygıyı da beraberinde getirmektedir. Arzuladığı beklentiye ulaşamadığı takdirde olması gerekenden daha fazla stres yaşadığı ileri sürülmektedir. Bu kişiler başarıya önemli ölçüde angaje olmuş durumdadırlar. Bu tip bireyler kendilerini işine adamışlardır. Aynı anda birden fazla işi yürütebilirler. Uzun süre baskı altında çalışabilmektedirler. Hareket halindedirler, hızlı yer ve hızlı yürürler. Sayılara önem vermektedirler. İşlerin niceliksel sonucuna odaklanmaktadırlar (Güney, 2017, s.1; Robbins ve Judge, 2015, s.143; Çetin ve Basım, 2014, s.114-115; Kunnanatt, 2003, s.722; Şimşek, Çelik and Akgemci, 2016, s.89; McKenna, 2010, s.32).

A tipi kişilik özelliklerinin tam tersi özelliklere sahip olanlar da vardır. Kurallarla barışık değildir ve esnektirler. Zaman baskısından hoşlanmazlar. Aşırı hırslı ve rekabetçi değillerdir. Üstünlük için değil eğlence için mücadele etmektedirler. Tedirgin edecek durumlardan uzak durmaktadır. Rahattırlar ve bu durumdan suçluluk duygusu taşımazlar. Ancak sakin oldukları kadar düzenli bir şekilde çalışmaktadırlar. Sağlıklı olmaya çalışır ve iş ortamındaki rekabetten fazla etkilenmezler. Daha gerçekçi yaklaşımları bulunmaktadır. Ancak bu kişilik tipine sahip kişiler az da olsa A tipi kişilik davranışlarını da sergileyebilirler. Birçok davranışları yavaş tempodadır. Sabır düzeyleri yüksektir (Güney, 2017, s.19). Ancak yine de bu tip kişiliğe sahip bireylerin A tipi kişiden daha az başarılı olduğu iddia edilemez (Robbins ve Judge, 2015, s. 143; Çetin ve Basım, 2014, s.114-115; Kunnanatt, 2003, s.722; Şimşek, Çelik and Akgemci, 2016, s.89; Durna, 2004, s.200; Thorne-Figueroa, 2010, s.15; McKenna, 2010, s.38). 
Bir insan sadece A tipi ya da B tipi bir kişilik olduğunu söylemek zordur. Ancak bunlardan birine daha fazla eğilimli olabilmektedir. Söz gelimi bir insan kısa süreliğine zaman kavramını unutup rahat davranabilir. Yüksek sesle konuşan birinin kütüphanede yavaş konuşması gibi koşullara az da olsa uyum göstermektedir (Durna, 2004, s.200). Diğer yandan A tipi kişilik özelliği iş ortamında meydana gelen olumsuzluklara veya belirsizliklere karşı tepki gösterirken nadiren değişim göstermektedirler. Dolayısıyla davranışlarını tahmin etmek B tipi kişilik özelliğine göre daha kolaydır. İşe kabul edilme noktasında A tipi kişiliğin daha fazla tercih edildiği ileri sürülmektedir. Çünkü daha fazla yeterliliğe, girişkenliğe ve yüksek motivasyona sahip olduğu düşünülmekte ve değerlendirilmektedir (Robbins ve Judge, 2015, s.144; Gümüştekin ve Gültekin, 2009, s. 2). Öyle ki yapılan bir araştırmanın bulgularına göre Amerika'daki yöneticilerin \%60'ının A ve \%12'sinin de B tipi kişilik özelliğine sahip olduğu saptanmıştır. A tipi kişilik özelliğine sahip bireylerin çağın gerektirdiği gibi hızlı ve hareketlidirler. Büyük olasılıkla bu yüzden daha fazla tercih edilmektedirler (Soysal, 2008, s.10).

A tipi kişilik davranışları genellikle genç yetişkinlikte takdir edilir ve ödüllendirilir. Çünkü bu bireyler enerjik, adanmış ve memnun etmeye istekli olarak görülmektedir (Thorne-Figueroa, 2010, s.17). Diğer yandan A tipi kişiler karar verme süreçleri daha hızlı o nedenle etkili karar veremezler. Sonuç ve niceliksel başarı odaklı oldukları için inovatif yönleri daha zayıftır (Çetin ve Basım, 2014, s.115).

A tipi kişiliğin stres düzeyinin daha yüksek olduğu bir gerçektir. Nitekim A tipi kişilik yoğunluğu arttıkça stres düzeyinin arttığı tespit edilmiştir (Şahin, Güler \& Basım, 2009, s.250). Fakat B tipi bireylerin hiç strese girmediği söylenemez. Ancak B tipi kişilik stresin etkisinde kolayca kurtularak normal hayatına dönebilir. Diğer bir ifadeyle B tipi bireylerin başarı şanslarının daha yüksek olduğu ifade edilebilir (Gümüştekin ve Gültekin, 2009, s.2). Erden ve arkadaşları (2012) A tipi kişilik özelliğine sahip bireylerin daha fazla işkolik olduğunu ortaya koymuşlardır. Fakat bu her zaman B tipi kişilikten daha iyi performans göstereceği anlamına gelmez. Dikkat ve odaklanma gerektiren işlerde, takım çalışmalarında ve sabır gerektiren görevlerde daha metanetli olmaları nedeniyle başarılı olamayabi- 
lirler. Bu tür görevlerde B tipi kişiliğin daha uygun olacağı düşünülmektedir. Bu tür durumlarda A tipi kişilerin agresif ve saldırgan davranmaları daha olasıdır (Özdevecioğlu ve Aksoy, 2005, s.97).

\section{Kariyer ve Akademik Destek}

Akademik danışmanlık literatürü içerisinde araştırmacılar danışmanlığın ne olduğunu ve kilit bileşenlerinin neler olduğunu ele almaya çalıştığı görülmektedir. Danışmanlığın öğrencilerin başarısını olumlu yönde etkileyip etkilemediği ise halen incelenmeye devam edilmektedir (Crisp, 2009, s. 177).

Bazı araştırmacılar, danışmanlık tanımını belli kalıplara soksalar da, bazıları danışmanlığı, bireyi öğreten ya da bireyin gelişmesine imkân tanıyan bir ilişki olarak tanımlamaktadır. Söz gelimi Luna ve Cullen'e (1995) göre danışmanlığın, formal ya da informal, uzun veya kısa vadeli ve planlı veya kendiliğinden geliştiğini ifade etmektedir. Tecrübeli ve bilgili bir insanın, tecrübesiz bir kişinin kariyerini ve kişisel gelişimini kolaylaştıracak şekilde öğrenmesini desteklemesi için üstlendiği resmi ve sınırlı bir süreçtir. Öğrencilerin birçok problemine çözüm bulmak amacıyla gerçekleşen eğitimsel bir süreç ve samimi bir bağdır (Seçkin, Aypay and Apaydın, 2014, s. 2). Öğrencinin gelişiminde oynanan kritik rol, zaman ve çaba gerektiren bir oyunculuktur (Lynch ve Lungrin, 2018, s.70). Gelişim, kariyer ve yaşam hedeflerine ulaşmaya yardımcı olan etkileşimli danışmanlık ve yönetim stratejisidir. Kendini yönetme becerilerini geliştirme, öz-güven sağlama ve bireysel potansiyeli güçlendirme sürecidir (Creamer ve Creamer, 1994, s.19). Öğrencilerin kendi kişisel ilgi alanlarının, yeteneklerinin, değerlerinin, fikirlerinin neler olduğu ve kariyer hedeflerini bu doğrultuda nasıl oluşturacaklarını anlamalarına yardımcı olan dinamik ve etkileşimli bir süreçtir (Gordon, 2006, s.12; Adena vd., 2013, s.9). Danışmanlık bir öğrenci destek hizmetidir (Hughey ve Hughey, 2009, s.8). Danışmanlık hedeflerin belirlenmesiyle ilgilidir. Hedefler; akademik, kariyer ve kişisel gelişim desteğini ve alanlarını kapsamaktadır (Ender ve Wilkie, 2000, s.119).

Akademik ve kariyer desteği öğrencilerin gelişimine değer katmakta ve öğrencileri geleceğe daha etkili şekilde hazırlayabilmektedir. Ancak 
öğrencilerin kişisel sorumluluk almaları gerekmektedir. Diğer yandan danışmanların bu süreci kolaylaştırma gibi kritik bir rolü bulunmaktadır. Öğrencilerin iş dünyasını keşfetmesini, kariyer hedeflerini netleştirmesini, kariyer hedeflerine uygun eğitim kombinasyonlarını araştırmasını sağlaması gerekmektedir (Hughey ve Hughey, 2009, s.6). Buradan yola ç1kılarak danışmanlığın bilgi vermekten daha fazlası olduğu söylenebilir. Danışmanlık, öğrenci merkezli bir ilişkiyi ve öğretirken öğrenmeyi de mümkün kılmaktadır. Danışmanlık yapmak, öğrencilerin ve toplumun geleceğinin inşa edilmesinde önemli bir hizmettir (Hughey ve Hughey, 2009, s.8). Öğrencilerin öz-yeterliliğin geliştirilmesinden pratik becerilerin pratik uygulamalarına kadar uzanan tüm yönlerinin canlı kalmasını sağlamaktadır (Adena vd., 2013, s.15). Öğrencilerin istihdam edilmesinde kısmen de olsa güvence sağlamaktır (Crisp, 2009, s.177). Bu nedenle kariyer ve akademik desteği, danışmanlara anlamlı bir iş yaptıkları, dolayısıyla anlamlı bir amaç edindikleri hissini vermektedir. Bir öz aşmışlık duygusu aşılamaktadır. Danışmanlık yapan birinin, bir başkasının kendini gerçekleştirmesinde yardımcı olduğu söylenebilir.

Akademik ve kariyer danışmanlığ 1 konusunda geliştirilmiş birden fazla ölçek ve teori bulunmaktadır. Ancak bu çalışmada; eğitim, psikoloji ve yönetim literatürünün teorik perspektiflerini birleştiren, Nora ve Crisp (2007, s.342-343) tarafından geliştirilen mentörlük teorisinden yararlanılmıştır (Crisp ve Cruz, 2010, s.234). Danışmanlık ve rehberlik eğitiminin üniversite öğrencileri tarafından birbiriyle ilişkili dört boyut olarak alg1landığ1 ve deneyimlendiği öne sürülmektedir. Bu değişkenler; (1) Psikolojik ve Duygusal Destek, (2) Derece ve Kariyer Desteği, (3) Akademik Alan Bilgisi Desteği ve (4) Rol Modeli şeklinde siralandığg görülmektedir (Nora ve Crisp, 2007, s.342-343; Crisp, 2009, s.178; Crisp ve Cruz, 2010, s.234; Gök ve Aydın, 2017, s.110).

Bunun yanında literatür incelendiğinde Crisp'in Derece ve Kariyer Desteği ile Akademik Alan Bilgisi Desteği boyutlarını birleştirerek "Kariyer ve Akademik Destek" faktörünü oluşturduğu; geri kalan Psikolojik ve Duygusal Destek ile Rol Modeli boyutlarını da "Psikolojik, Duygusal ve Sosyal Destek" çatısı altında topladığı tespit edilmiştir (Gök ve Aydın, 2017, s.112). Buradan hareketle bu çalışmada Kariyer ve Akademik Destek boyutlarına ilişkin maddelerden oluşan tek maddeli bir ölçek uygulanmıştır. 
Psikolojik ve Duygusal Destek; ahlaki ve duygusal destek, dinleme duygusu gibi konularda destekleyici ilişkilerin kurulmasını ifade etmektedir. Bu sayede danışman ile danışan arasında kurulan ilişki neticesinde bir bağ kurulmuş olmaktadır. Korku ve belirsizliklerin tartışıldığ 1 ve gerekli çözümlerin üretilerek özgüvenin oluşturulduğu bir ortamı kapsamaktadır. Derece ve Kariyer Desteği, öğrencinin güçlü/zayıf yönlerini ortaya koyan, sahip olduğu yeteneklerini değerlendiren, akademik/kariyer hedeflerini belirleyen ve karar verme sürecini kolaylaştıran çok yönlü bir boyuttur. Öğrencinin ilgi, yetenek ve fikirleri araştırılmaktadır. Kişisel ve mesleki potansiyeli geliştirilmektedir. Eleştirel düşünme becerileri uyarılmaktadır. Amaçları anlaşılmaya çalışılarak hedeflerine ilerleme süreci tartışımaktadır. Akademik Alan Bilgisi Desteği; bu boyutta danışman, öğrencinin bilgi ve becerisi üzerinde odaklanmakta ve bunları geliştirmeye çalışmaktadır. Öğrencinin akademik eğitimi açısından geliştirmekte, düzeyini değerlendirmekte ve bu konuda mücadele etmesi için yol ve yöntem göstermektedir. Rol Modeli; öğrenciler her şeyi deneyimleyerek öğrenmeyebilirler. Bazen temsili öğrenme önemli bir araç olarak kullanılmaktadır. Bu noktada danışmanın ışık olması açısından tecrübelerini aktarması gerekmektedir. Burada aynı zamanda danışmanın kendini açması sonucunda öğrenciyle aralarındaki ilişki ve duygusal bağın da kuvvetlenmesi söz konusu olmaktadır. Nitekim öğrencilerle kurulan ilişkiler öğrenme sürecini geliştirmede temel oluşturmaktadır (Walters-Archie, 2018, s. 870).

\section{Kariyer Uyum Yetenekleri}

Kariyer kavramı Latince de, at arabası anlamina gelen "Carrus" ve yol anlamına gelen "Carrera" kelimelerine karşılık gelmektedir. Bunun yanında Fransızca' da, iş/meslekte hız ve ustalık anlamına gelen "Carrierre" ve İngilizce'de de meslek anlamını karşılayan "Career" sözcügüüle ifade edilmektedir. Türkçe'deki karşılığı da bu kelimelerden türetildiği ifade edilmektedir (Bingöl, 2013, s.329; Güney, 2014, s.145-146; Ertürk, 2011, s.201). Günümüzde ise bu kavram için farklı tanımlar geliştirilmiştir. Kariyer kavramı, bireyin iş ve meslek hayatında sergilemek zorunda olduğu rolleri ve iş hayatı boyunca üstelendiği sorumluluklardır (Taşlıyan, Arı \& Düzman, 2011, s.233). Bu rollerin sıralaması ve birbiriyle olan ilişkinin bir 
bileşimidir (Super, 1980, s.282). Bireyin hayatı boyunca edindiği bilgi, beceri ve kazandığı statüyü açıklayan kavramdır. Diğer yandan kariyer, hayatı anlamlı haline getiren bir kimliktir (Güney, 2014, s.147). Bir örgütte veya bir hiyerarşik sistemde yukarıya doğru bir hareketliliktir (Erdoğmuş, 2003, s.11). Nitekim bir bireyin sahip olduğu meslek, onu topluma bağlayan bir mekanizma ve sosyal bütünleşme aracı olmaktadır (Savickas ve Porfeli, 2012, s.663).

Kariyer uyumluluğu, bireyin hayatı boyunca mesleki gelişimi üzerinde bir mercek işlevi olan Kariyer Yapılandırma Kuramı üzerinde inşa edilmiştir. İnsanların kariyer seçimlerini ve geçişlerini yapma konusunda hissettikleri endişe/ilgi, güven, kontrol ve merak düzeyleriyle ilgili olduğu görülmektedir (Buyukgoze-Kavas vd., 2015, s.122). İnsanlar, kişiliklerini iş rollerinde uygulayarak ve uyarlanabilir stratejiler kullanarak kariyer yapmaktadırlar. Uyumluluk olarak ifade edilen bu adaptasyon, iç ihtiyaçları ve dış fırsatları değerlendirmek suretiyle yönlendirilmektedir. Kariyer uyum teorisinin bir türevi olan kariyer uyum yetenekleri, bireylerin iş ve özel hayatlarını başarıyla yönetmelerinde önemli bir faktör olan zihinsel ve duygusal özelliklerdir. Bu özelliklerin yüksek düzeyde olması kişinin kariyer hayatı boyunca dirençli olmasını sağlamaktadır (Yeşiltaş, Akdağ, Çeken \& Gürlek, 2014, s.1286). Kariyer uyumu ergenlerde ya da yetişkinlerde planlı tutumlar, kendini tanımayı ve çevreyle ilgili araştırmayı ve bilinçli karar vermeyi gerektirmektedir (Savickas, 1997, s. 254). Buna bağlı olarak kariyer uyum yetenekleri eğitim ve tecrübe yoluyla kazanılmış birikimler, yetkinlikler ve bilgi olarak tanımlanmaktadır (Savickas ve Porfeli, 2012, s. 662; Tolentino vd., 2014, s. 40). Kariyer uyum yetenekleri; bireyin mesleki geçiş süreçlerin ve kişisel travmaların üstesinden gelebileceğine dair hazır olma durumunu gösteren psikolojik bir yapıdır (Yousefi vd., 2011, s. 264). Karmaşık ya da kötü tanımlanmış sorunları çözmek için kişinin güvenebileceği çok yönlü ve dinamik öz-denetim mekanizması ya da kapasitesidir (Šverko ve Babarović, 2016, s.91; Autin vd., 2017, s.2).

Kariyer uyum yetenekleri kaynakları dört bileşenin bir araya gelip sinerji oluşturmasıyla meydana gelen bir çatı kavramıdır. Bu bileşenler, yabancı literatürde $4 \mathrm{C}$ olarak ifade edilmektedir. Bunlar ise concern (ilgi), control (kontrol), curiosity (merak) ve confidence (güven) olduğu görülmektedir. Illgi; mesleki bir geleceğin farkında olmayı, pozitife odaklanmayı ve planlamayı ifade etmektedir. Bireylerin ileriye bakmalarına ve bir 
sonraki aşamalarda neler yapabileceğine ilişkin hazırlık yapmasına yardımcı olmaktadır. Kontrol; bireylerin kendi disiplinini, çabasını ve kararlılığını kullanarak geleceği karşılama ve ileride iş sorumluluğunu alma düzeyini göstermektedir. Bir kişinin çeşitli durumlarda ve rollerde kendini düzenleme ve yönünü tayin etme isteğini ifade etmektedir. Merak; bireyin kendi çevresini araştırma, keşfetme, bilgi edinme, yetkinlik kazanma ve risk alma eğilimini ifade etmektedir. Bu sayede bireyler iş dünyası hakkındaki bilgisini arttırmakta ve keşif davranışlarını da geliştirmektedir. Güven; kariyerle ilgili zorlukların üstesinden gelme, direnç gösterme ve başarılı bir şekilde sorun çözme konusunda kişinin kendinden emin olma duygusunu ifade etmektedir. Bireyin sahip olduğu yeteneklerine güven duymasıdır (Savickas ve Porfeli, 2012, s.663; Autin vd., 2017, s.2; Buyukgoze-Kavas vd., 2015, s.123; Coetze ve Harry, 2013, s.3).

\section{Kişilik Tipi, Kariyer ve Akademik Destek ile Kariyer Uyum Yetenekleri İlişkisi}

Super, kariyer gelişiminin bireyin tüm hayatına yayılan bir süreç ve çevresel koşullara bağlı olarak meydana gelen benlik oluşumunun bir mesleğe yansıması olduğunu ileri sürmektedir. Dolayısıyla kişisel kimlik değişimine bağlı olarak kariyer tercihleri de değişmektedir (Ünsal, 2014, s.310). Kişi bunu yetenekleriyle ve çabalarıyla neler yapabileceğini keşfetme, kendisi hakkında alg1 oluşturma, diğer kişilerle özdeşleşme gibi yollarla gerçekleştirmektedir (Ünsal, 2014, s.307-308; Erdoğmuş, 2003, s.55;).

Kariyer gelişimi, eğitim hayatını kapsadığından dolayı öğrenciler gerçek çalışma hayatına girmeden önce kariyerleri üzerinde çalışmaya başlamaktadırlar. Bu nedenle, öğrencilerin gelecekteki iş yaşamları, kişilik özellikleri, kariyer uyumluluğu ve akademik başarıları öğrencilik hayatları boyunca karşılıklı ve aktif olarak bağlantılı olduğu ileri sürülmektedir (Negru-Subtirica ve Pop, 2016, s.163). Hatta öğrencilerin eğitim sisteminde gittikçe daha uzun zaman geçirmekte ve kariyer hedefleri ile eğitim hedefleri iç içe geçtiği görülmektedir (Roeser vd., 2000, s.466).

Kariyer gelişimi üzerinde çalışırken kişilik faktörü de göz önünde bulundurulması gereken kilit bir unsur olduğu unutulmamalıdır (Marcionetti ve Rossier, 2017, s.3). Kişiliğin erken dönemlerinde meslek seçimi, o 
kişiliği birçok yönden ortaya koymaktadır. Aslında seçilen meslek; kişiliğin özelliklerini, öğrencinin bilgisini, yeteneklerini, arzularını ve ilgilerini sergilemektedir (Yeşilyaprak, 2015, s.208- 209). Örgüt içerisinde yapılması gereken bir işin ve o işi gerçekleştirecek bireyin kişilik yapısıyla olan uyumuna dikkat edilmesi gerekmektedir. Bunu başarabilen örgütlerin daha başarıll, verimli, rekabet gücü yüksek ve iş gücü devir oranın düşük olduğu ileri sürülmektedir (Şimşek vd., 2016, s.94-95). Kişi ile iş uyumunun artması bireysel başarıyı arttırmaktadır. O nedenle seçilen iş ile kişilik yapısının örtüşmesine önem verilmelidir (Özkalp, 2015, s.48).

Birey, hayatına yön verecek ilk kariyer kararını verme konusunda istekli davranmaktadır. Öğrenciler, erken yaşlarda farkına varmadan mesleki bakımından önemli kararlar aldıkları görülmektedir (Ünsal, 2014, s.277, 279). Ne var ki üniversite öğrencilerinin çoğu kariyer kararı verme konusunda önemli problemler yaşamaktadır. Birçok üniversite öğrencisinin bu aşamada ebeveynlerinden, akademisyenlerden ve arkadaşlarından destek aldığı ve yönlendirildiği görülmektedir (Mortimer, Zimmer-Gembeck, Holmes and Shanahan, 2002, s.464). Bu noktada akademisyenlerin, danışmanların ve ailenin desteği, öğrencilerin geleceği için bir dönüm noktası oluşturduğu söylenebilir. Öğrencilerin genç yaşta mesleki tercihlerini yaparken doğru yönlendirilmesi, kişilik özelliklerine göre bir kariyer yoluna kanalize edilmesi akademik danışmanların önemli bir sorumluluğudur. Bu konudaki danışmanların rolü öğrencilerin ileriki hayatını şekillendireceği unutulmamalıdır. Etkili ve verimli bir danışmanlık süreci sonucunda mesleki geleceğe ilişkin olumlu görüşlerin güçlendiği de görülmektedir (Negru-Subtirica ve Pop, 2016, s.163).

Öğrencilerin geleceğe ilişkin güçlü yönelimi onların kariyer planlama faaliyetlerine, daha iyi performans ve yüksek akademik başarı göstermelerine zemin hazırlamaktadır. Akademik başarı, öğrencilerin hem mezuniyete doğru yaptıkları mesleki tercihlerini (Schnabel vd., 2002, s.183) hem de motivasyonlarını ve öğrenme stratejilerini doğrudan etkilemektedir (Negru-Subtirica ve Pop, 2016, s.163-164).

Son yıllarda birçok üniversite öğrencisi ve onlara danışmanlık edenler için uygun akademik ve kariyer kararları vermek bilmeceyle dolu zorlu ve kaygılı bir görev olabilmektedir (Bullock, Reardon and Lenz, 2007 211). Günümüzde bu durum, özellikle birçok kararsız öğrenci için en önemli endişelerinden biri olmaya devam etmektedir (Lynch ve Lungrin, 2018, 
s.69). Birçok öğrenci kendi ilgi, beceri ve değerlerinin farkında olmadığ 1 ileri sürülmektedir (Bullock, McConnell \& Schedin, 2014, s.22). Bu öğrencilerin iş dünyasının beklentilerinden habersiz olduğu görülmektedir. $\mathrm{O}$ nedenle danışmanlık hizmeti ve çabaları öğrencilerin kariyer planlama ve kariyer gelişimini desteklemesi açısından gereklidir (Lynch ve Lungrin, 2018, s.70). Bu sayede akademik danışmanlar öğrencilerin hayatına dokunmakta ve kaygılarını azaltmaktadırlar (Cunningham ve Smothers, 2014, s.23). Bu açıdan irdelendiğinde etkili danışmanlık, öğrencilerin hayatına somut olarak dokunmak için bir fırsat olduğu söylenebilir (Hughe ve Hughey, 2009, s.1; Kuhn, Gordon and Webber, 2006, s.26). O nedenle öğrencilere danışmanlık yapmak hiç bu kadar zorlayıcı, heyecan verici ve önemli olmadığı ifade edilmektedir (Gordon, 2006, s.5).

Literatürde yer alan yukarıdaki bilgiler ışığında aşağıdaki hiptezler geliştirilmiştir.

- H1: A tipi kişilik özelliklerinin kariyer uyum yetenekleri üzerinde anlamlı bir etkisi vardır.

- H2: B tipi kişilik özelliklerinin kariyer uyum yetenekleri üzerinde anlamlı bir etkisi vardır.

- H3: A tipi kişilik özelliğine sahip bireylerde kariyer ve akademik desteğin kariyer uyum yetenekleri üzerinde anlamlı bir etkisi vardir.

- H4: B tipi kişilik özelliğine sahip bireylerde kariyer ve akademik desteğin kariyer uyum yetenekleri üzerinde anlamlı bir etkisi vardır.

- H5: Kariyer ve akademik desteğin kariyer uyum yetenekleri üzerinde anlaml bir etkisi vardir.

\section{Araştırmanın Yöntemi}

\section{Araştırmanın Amacı ve Modeli}

$\mathrm{Bu}$ araştırmanın amacı, öğrencilerin sahip oldukları kişilik tipinin kariyer uyum yeteneklerine olan etkisini araştırmaktır. Fakat sosyal bilimlerde bir bağımlı değişkenin sadece bir bağımsız değişkenden etkilendiğini söylemek mümkün görülmemektedir. Dolayısıla kariyer uyumu yeteneklerini etkileyen ikinci önemli bir değişken olarak da eğitimcilerin kariyer ve akademik desteğinin rolü ortaya konulmaya çalışılmıştır. Bunun yanında A ve B tipi kişilik farklılığı bağlamında kariyer ve akademik desteğin rolü 
araştırılmıştır. Bu amaç doğrultusunda şekil 1'de gösterilen bir model oluşturulmuştur.

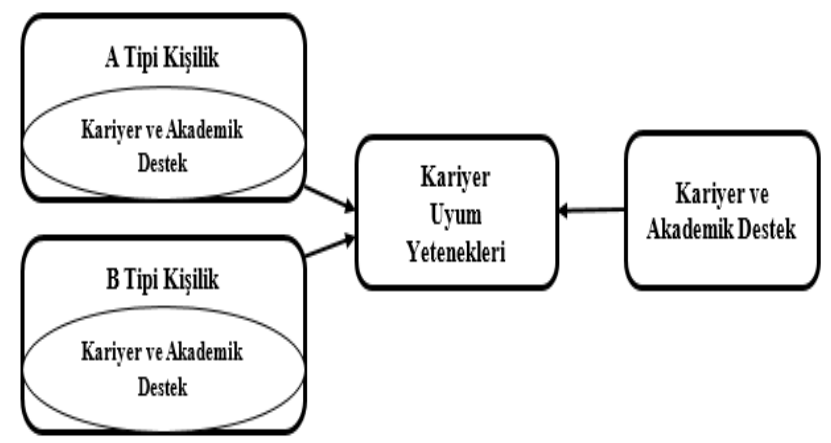

Şekil 1: Araştırmanın Modeli

\section{Araştırmanın Evreni ve Örneklemi}

Bu çalışmada seçilen evren kitlesi olarak 2018-2019 eğitim - öğretim güz döneminde Burdur Mehmet Akif Ersoy Üniversitesinin lisans 4. Sinıf ve iş hayatına atılmamış lisansüstü öğrencilerinden oluşmaktadır. Fakat araştırma evreninin geniş olması nedeniyle kümeleme örneklem yöntemiyle bir örneklem kitlesi seçilmiştir. Buna göre, mezun olduktan sonra birçok işi tercih edebilme olanağına ve geniş bir kariyer yelpazesine sahip olan üniversitenin İktisadi ve İdari Bilimler Fakültesinde 4. sınıf öğrencileri ve Sosyal Bilimler Enstitüsünde eğitime devam eden ve herhangi bir işte çalışmayan lisansüstü öğrencileri seçilmiştir. İ.İ.B.F'den 436 ve Sosyal Bilimler Enstitüsünden ise 82 olmak üzere toplamda 518 katılımcıdan veri toplanmıştır. Fakat veri ayıklama sürecinde 19 anket değerlendirme d1şında bırakılmıştır. Geriye kalan 499 anketten oluşan bir veri seti üzerinden analizler gerçekleştirilmiştir.

Bu çalışmada, katılımcılardan veri toplamak amacıyla anket formu kullanılmıştır. Bu anket formunda "A ve B Kişilik Ölçeği", "Kariyer Uyum Yetenekleri Ölçeği" ve "Kariyer ve Akademik Destek Ölçeği" olmak üzere toplamda üç farklı ölçek kullanılmıştır. 


\section{Veri Toplama Araçları}

A ve B Kişilik Ölçeği (A/BKÖ): Öğrencilerin kişilik tipini ölçmek amacıyla yedi ifadeden oluşan A ve B kişilik tipi ölçeği uygulanmıştır. Friedman ve Rosenman (1978) tarafından geliştirilen bu kısa ölçek, Aktaş ve Arıkan tarafından 1988 yılında Türkçeye uyarlanarak geçerlilik ve güvenirliği test edilmiştir (Arıkan ve Aktaş, 1988, s.725). Bu ölçek, 8 dereceli Likert tipi bir ölçektir. Katılımcılardan kendilerine en yakın olan rakamı seçmeleri istenmektedir. Bu seçimler sonucunda işaretlenen rakamların toplamı üç ile çarpılmaktadır. Toplam puan 100'den büyük ise A tipi kişilik, 100' den küçük ise B tipi kişilik özelliklerini taşıdığı kabul edilmektedir (Aktaş, 2001, s.34).

Kariyer Uyum Yetenekleri Ölçeği (KUYÖ): Her biri 6 maddeye sahip ilgi, kontrol, merak ve güven olmak üzere 4 boyuttan oluşmaktadır. Bu ölçek Savickas ve Profeli'nin (2012) tarafından geliştirilmiştir. KUYÖ'nün 13 farklı ülkede test edildiği, sonucunda ise güvenilir ve geçerli bir ölçüm aracı olduğu ispatlanmıştır. KUYÖ'de, 1) kesinlikle katılmıyorum ile 5) kesinlikle katılıyorum arasında değişen 5 dereceli bir Likert ölçeklendirme uygulanmıştır. Bu ölçeğin Türkçe uyarlaması ve dil eşdeğerliliği Kanten (2012) tarafından test edilmiştir.

$\mathrm{Bu}$ çalışmada, boyutların bir araya geldiğinde bir sinerji oluşturarak tek başlarına yaratacakları etkiden daha fazlasını oluşturacağı düşünülmüştür. Bu nedenle dört boyutun ortalaması alınarak "Toplam KUY" boyutu oluşturulmuştur.

Kariyer ve Akademik Destek Ölçeği (KADÖ): Bu ölçek, Crisp (2009) tarafından geliştirilmiştir. Ölçek, 4 boyut ve 25 maddeden oluşmaktadır. Yapılan güvenirlik ve geçerlilik testleri başarıyla olumlu sonuçlar vermiştir. Ölçek 5 dereceli bir Likert tipi ölçektir. Buna göre 1) kesinlikle katılıyorum ve 5) kesinlikle katılmıyorum şeklinde sıralanmaktadır. Bu ölçeğin Türkçe dil eş değerliliğini, geçerlilik ve güvenirlik çalışmasını Gök ve Aydın (2010) tarafından yapılmıştır.

Bu çalışmada ise, öğrencilerin kariyer hayatını somut şekilde etkileyen ve geniş ölçüde kariyer tercihlerinin belirlenmesini ve yönlendirilmesini 
ölçen Derece ve Kariyer Desteği ile Akademik Alan Bilgisi Desteği boyutlarının birleşiminden oluşan "Kariyer ve Akademik Destek Ölçeği" kullanılmiştır.

Yukarıda verilen üç farklı ölçeğin boyutlarına ilişkin bu çalışmada elde edilen Cronbach Alpha güvenirlik değerleri tablo 4' te gösterilmiştir. Tablo 4'e göre hem bir bütün olarak ölçeklerin güvenirlik değerleri hem de ölçeklerin tüm alt boyutlarının güvenirlik değerleri kabul edilebilir düzeyde olduğu tespit edilmiştir.

\section{Ölçeklere İlişkin Doğrulayıcı Faktör Analizleri}

Doğrulayıcı faktör analizi (DFA), geliştirilmiş veya Türkçeye uyarlanmış ölçeklerin kuramsal yapısını istatistiksel olarak doğrulamak amacıyla kullanılan bir yapısal eşitlik modeli türüdür. DFA ile gözlenen ve örtük değişkenler arasındaki ilişki ortaya konulmaktadır. DFA sonucunda elde edilen uyum indeksleri incelenerek mevcut çalışmanın modeliyle kuramsal yapının modelinin uyumu test edilmektedir. Uygulanan ölçeklerin kuramsal yapıya uygunluk göstermesi geçerlik ve güvenirlik açıdan uygunluğunu göstermektedir (İlhan ve Çetin, 2014, s.29).

Bu çalışmada DFA yapılırken kişilik ölçeğinden kişilik3, kişilik6 ve kişilik7 maddeleri uyum indeksi değerlerini düşürmeleri nedeniyle çıkarılmış olup, kişilik4 ve kişilik5 maddeleri arasında ise modifikasyon işlemi yapılarak birbirine bağlanmıştır. Kariyer ve destek ölçeğinden ise kariyer desteğini ölçen kardest1 ile kardest2, kardest2 ile kardest3 ve kardest4 ile kardest5 maddeleri birbirine bağlanmıştır. Son olarak da kariyer uyum yetenekleri ölçeğinden ilgi1, kontrol1 ve merak6 maddeleri çıkarılmıştır. Bunun yanında merak2 ile merak3, merak2 ile merak4, güven1 ile güven2, güven3 ile güven 4 ve güven5 ile güven6 maddeleri arasında yapılan modifikasyon işlemi sonucunda birbirine bağlanmıştır. Uyum indekslerinin bu çalışmada çıkan sonuçları ise Tablo 1'de gösterilmiştir. Bu tabloda olması gereken normal değerler, kabul edilebilir asgari değerler (Papatya, Papatya \& Hamşığlu, 2016, s. 32; Kocagöz ve Dursun, 2010, s.145) ve bu çalışmada kullanılan ölçeklere ilişkin elde edilen bulgular gösterilmiştir. 
Tablo 1. Doğrulayıcı Faktör Analizine İlişkin İndekslerin Uygunluk Değerleri ve Ölçeklerin Aldiğı Değerler Tablosu

\begin{tabular}{|c|c|c|c|c|c|}
\hline $\begin{array}{l}\text { İn- } \\
\text { deksler }\end{array}$ & Normal Değerler & $\begin{array}{l}\text { Kabul Edilebilir } \\
\text { Değerler }\end{array}$ & $\begin{array}{l}\text { A/BKÖ } \\
\text { Değerleri }\end{array}$ & $\begin{array}{l}\text { KADÖ } \\
\text { Değerleri }\end{array}$ & $\begin{array}{l}\text { KUYÖ } \\
\text { Değerleri }\end{array}$ \\
\hline$\chi 2 / s d$ & $0 \leq \chi 2 / s d \leq 3$ & $3 \leq \chi 2 / s d \leq 5$ & 2.51 & 4,12 & 2.87 \\
\hline GFI & $.95 \leq \mathrm{GFI} \leq 1.00$ & $.90 \leq \mathrm{GFI} \leq 95$ & 1.00 & .94 & .91 \\
\hline AGFI & $.90 \leq$ AGFI $\leq 1.00$ & $.85 \leq \mathrm{AGFI} \leq .90$ & .97 & .91 & .88 \\
\hline CFI & $.95 \leq \mathrm{CFI} \leq 1.00$ & $.90 \leq \mathrm{CFI} \leq .95$ & .99 & .99 & .96 \\
\hline NFI & $.95 \leq \mathrm{NFI} \leq 1.00$ & $.90 \leq \mathrm{NFI} \leq .95$ & .99 & .98 & .94 \\
\hline RMSEA & $.00 \leq$ RMSEA $\leq .05$ & $.05 \leq$ RMSEA $\leq .08$ & .05 & .07 & .06 \\
\hline \multicolumn{6}{|c|}{$\begin{array}{l}p-\text { value }=0.00000 \\
\text { A/BKÖ: A ve B Tipi Kişilik Ölçeği } \\
\text { KUYÖ: Kariyer Uyum Yetenekleri Ölçeğ } i \\
\text { KADÖ: Kariyer ve Akademik Destek Ölçeğgi }\end{array}$} \\
\hline
\end{tabular}

Bu çalışmada uygulanan üç ölçeğinin DFA analizinin sonucu incelendiğinde tüm maddelerin standartlaştırılmış yüklerini gösteren $t$ değerlerinin 1,96' dan büyük olduğu tespit edilmiştir. Bu sonuç ölçeklerin her birinin tüm maddelerinin ilgili faktörlere yüklerinin istatistiksel olarak anlamlı olduğunu göstermektedir. Tablo 1'de verilen indeksler incelendiğinde ise modelin kuramsal yapısının istatistiksel olarak doğrulandığ 1 ifade edilebilir. Tablo 1'e göre her bir ölçeğin en az kabul edilebilir düzeyde uyum indekslerine sahip olduğunu göstermektedir.

\section{Araştırmanın Bulguları}

\section{Demografik Bulgular}

Çalışmaya katılan katılımcıların; toplam olarak cinsiyet dağılımları, eğitim düzeyleri bağlamında cinsiyet dağılımı ve kişilik tipine göre katılımcıların dağılımı Tablo 2'de gösterilmiştir.

Betimsel analiz sonucunda elde edilen bulgulara göre, katılımcıların $330^{\prime}$ u $(\% 66,1)$ kadın, $169^{\prime}$ u $(\% 33,9)$ ise erkeklerden oluşmaktadır. Sonuç olarak ortaya çıkan kadın-erkek arasındaki fark 161 kişiyle kadın katılımcıların daha fazla olduğu görülmektedir. Bunun yanında katılımcların 421'i $(\% 84,4)$ lisans ve $78^{\prime} \mathrm{i}(\% 15,6)$ ile lisansüstü öğrencilerinden oluşmaktadır. Lisans öğrencilerin 271'i (\%64,4) kadın ve 250'si (\%35,6) erkek iken lisansüstü öğrencilerin 59'u $(75,6)$ kadın ve 19’u $(\% 24,4)$ ise erkeklerden 
oluşmaktadır. Bu çalışmaya katılan öğrencilerin büyük bir çoğunluğu kadınlardan oluştuğu söylenebilir.

Tablo 2. Demografik Dağılım Tablosu

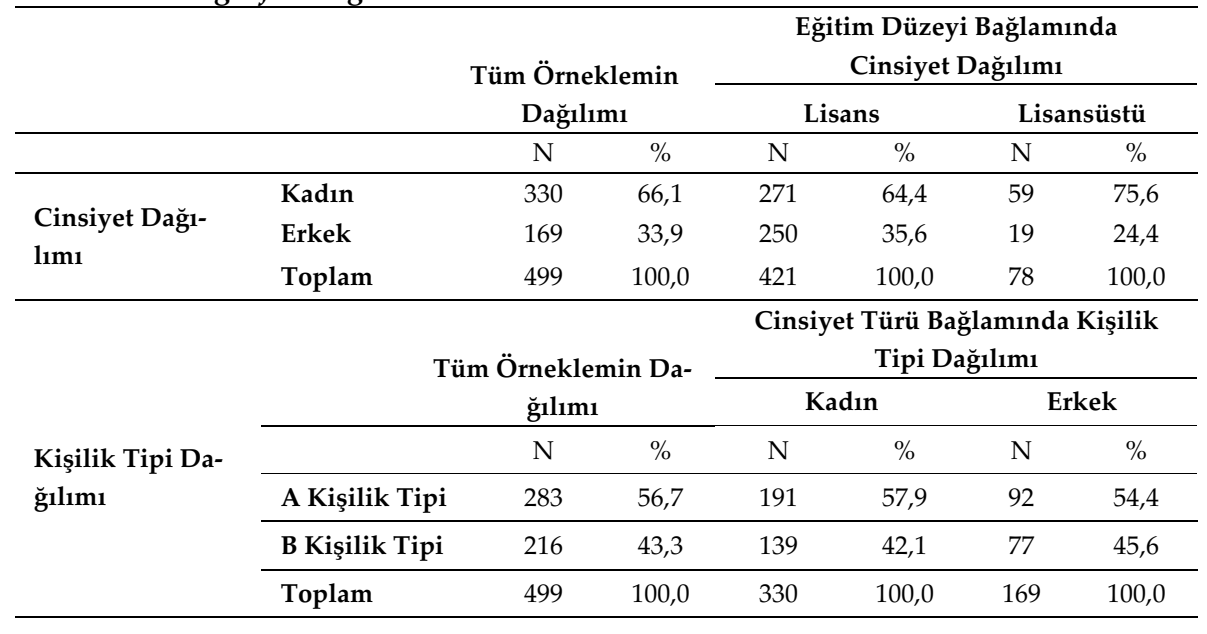

Bunun yanında bu çalışmada katılımcıların 283 ü $(\% 56,7)$ A kişilik tipi ve 216's1 (\%43,3) ise B kişilik tipine sahip olduğu görülmektedir. Kadınların 191'i $(\% 57,9)$ A, 139'u ise $(\% 42,1)$ B tipi kişiliğe sahipken, erkeklerin 92'si (\%54,) A ve 77'si $(\% 45,6)$ ise B tipi kişiliğe sahip olduğu görülmektedir. Buna göre genel olarak hem erkeklerde hem de kadınlarda A tipi kişiliğe sahip katılımcıların çoğunluğu oluşturduğu söylenebilir.

\section{Fark Testi Bulgular}

Katılımcıların eğitim düzeyi bağlamında ölçeklerin boyutlarına ilişkin algı ve görüşleri arasında anlamlı farklılığın olup olmadığını ortaya koymak amacıyla Bağımsız Örneklem T Testi uygulanmıştır. Elde edilen bulgular tablo 3'te gösterilmiştir.

Bulgulara göre; toplam KUY, ilgi, merak ve KADÖ değişkenlerinde, lisansüstü öğrencilerin lehine olan anlamlı bir farkın oluştuğu tespit edilmiştir $(\mathrm{p}<, 05)$. Kontrol boyutunda da anlamlı bir farkın olduğu görülmektedir $(\mathrm{p}<, 05)$. Fakat burada lisans öğrencilerin ortalamasının daha yüksek 
olduğu tespit edilmiştir. Diğer yandan güven boyutunda anlamlı bir farkın oluşmadığı $(p>, 05)$ ve iki grubun ortalamasının birbirine oldukça yakın olduğu saptanmıştır.

Tablo 3. Katılımcıların Ĕ̆itim Düzeyi Bağlamında Fark Testi Bulguları Tablosu

\begin{tabular}{|c|c|c|c|c|c|}
\hline & Eğitim Düzeyi & Ort. & S.S. & $\mathrm{p}$ & Anlamlı Fark \\
\hline \multirow{2}{*}{ İlgi } & Lisans & 4,89 & 60 & \multirow{2}{*}{, 000} & \multirow{2}{*}{ Lisansüstü $>$ Lisans } \\
\hline & Lisansüstü & 5,18 &, 48 & & \\
\hline \multirow{2}{*}{ Kontrol } & Lisans & 5,34 &, 53 & \multirow{2}{*}{$\lcm{043}$} & \multirow{2}{*}{ Lisans $>$ Lisansüstü } \\
\hline & Lisansüstü & 5,22 &, 45 & & \\
\hline \multirow{2}{*}{ Merak } & Lisans & 4,55 & ,74 & \multirow{2}{*}{, 000} & \multirow{2}{*}{ Lisansüstü $>$ Lisans } \\
\hline & Lisansüstü & 4,87 &, 55 & & \\
\hline \multirow{2}{*}{ Güven } & Lisans & 5,29 &, 59 & \multirow{2}{*}{,330 } & \multirow{2}{*}{ - } \\
\hline & Lisansüstü & 5,36 &, 50 & & \\
\hline \multirow{2}{*}{ Toplam KUY } & Lisans & 5,02 & 47 & \multirow{2}{*}{,004 } & \multirow[b]{2}{*}{ Lisansüstü $>$ Lisans } \\
\hline & Lisansüstü & 5,16 &, 36 & & \\
\hline \multirow{2}{*}{ KADÖ } & Lisans & 3,52 & 1,20 & \multirow{2}{*}{,000 } & \multirow{2}{*}{ Lisansüstü > Lisans } \\
\hline & Lisansüstü & 4,35 & 1,12 & & \\
\hline
\end{tabular}

Bu bulgularının yanı sıra, katılımcların cinsiyet ayrımı bağlamında ölçeklerin boyutlarına ilişkin algı ve görüşlerinde anlamlı farklılıklar ortaya konulmaya çalışılmıştır. Ancak elde edilen bulgular incelendiğinde sadece kariyer uyum yeteneklerinden olan kontrol boyutunda anlamlı bir farklılığa rastlanmıştır $(\mathrm{p}<, 05)$. Buna göre erkeklerin ortalamasının (ort.=5,43; S.S.=,49) kadinların ortalamasindan (ort.=5,26; S.S.=,52) daha yüksek olduğu tespit edilmiştir.

\section{İlişki Testi Bulgulan}

Kişilik, kariyer ve akademik destek değişkenleri ve kariyer uyum yetenekleri düzeyleri arasında anlamlı bir ilişkinin olup olmadığını ortaya koymak amaciyla yapılan pearson korelasyon analizi sonucunda elde edilen bulgular Tablo 4'te gösterilmiştir

Tablo 4 incelendiğinde kariyer uyum yeteneklerinden olan "kontrol" boyutunun KADÖ ile bir ilişkisi bulunmamaktadır ( $\mathrm{p}>$,05). A/BKÖ değişkeni, KADÖ, toplam KUYÖ ve bunun tüm boyutlarıyla yüksek düzeyde, anlamlı ve pozitif bir ilişkisinin olduğu tespit edilmiştir $(p<, 01)$. 
KADÖ’nun KUYÖ ve boyutları (kontrol hariç) arasında yüksek, anlamlı ve pozitif bir ilişkinin varlığı saptanmıştır $(\mathrm{p}<, 01)$.

Tablo 4. Korelasyon, Güvenirlik ve Ortalama Değerler Tablosu

\begin{tabular}{|c|c|c|c|c|c|c|c|c|c|}
\hline No & 1 & 2 & 3 & 4 & 5 & 6 & 7 & Ort & S.S. \\
\hline 1.KUYÖ & $(, 869)$ & & & & & & & 5,04 & ,46 \\
\hline 2.İlgi & ,741** & $(, 645)$ & & & & & & 4,94 &, 59 \\
\hline 3. Kontrol &, $707^{*+*}$ & ,320** & $(, 693)$ & & & & & 5,32 &, 52 \\
\hline 4. Merak &, $816^{*+*}$ &, $543^{* *}$ &, $375^{* *}$ & $(, 744)$ & & & & 4,60 &, 72 \\
\hline 5.Güven &, $770^{*+*}$ &, $370^{* *}$ &, $559^{* *}$ &, $455^{* *}$ & $(, 851)$ & & & 5,30 &, 58 \\
\hline 6. A/BKÖ & $474^{* *}$ &, $303^{* *}$ &, $357^{* *}$ &, $356^{* *}$ & , $432^{* *}$ & $(, 631)$ & & 4,34 &, 87 \\
\hline 7. KADÖ &, $218^{*+*}$ & $244^{* *}$ & ,039 & ,220** & $134^{* *}$ & $164^{* *}$ & $(, 936)$ & 3,65 & 1,22 \\
\hline $\begin{array}{l}{ }^{* *} P<, 01,{ }^{*} P \\
\text { Cronbach } A\end{array}$ & \multicolumn{8}{|c|}{${ }^{* *} P<, 01,{ }^{*} P<, 05$} & \\
\hline
\end{tabular}

Bu çalışmada tespit edilen yüksek ve anlamlı ilişkinin varlığı aynı zamanda değişkenler arasındaki etkinin (regresyon) varlığına işaret etmektedir. Bu nedenle değişkenler arasında regresyon testi uygulanarak elde edilen bulgular aşağıda gösterilmiştir.

\section{Etki Testi Bulguları}

Sosyal bilimlerde bir bağımlı değişkeni etkileyen birden fazla bağımsız değişkenin olması olasıdır. Buradan yola çıkılarak bir regresyon modelinde bağımlı değişkenin düzeyini etkileyen birden fazla bağımsız değişkenin ilişkisinin araştırılması gerekmektedir (Gürbüz ve Şahin, 2015, s.267). Buradan hareketle bu çalışmada Çoklu Regresyon analizi yapılırken Backward selection metodu uygulanmıştır. Bu metotta bağımsız değişkenler modele dâhil edilmektedir. En zayıf bağımsız değişken modelden atılır ve tekrar regresyon analizi yapılmaktadır. En yararlı regresyon modelini oluşturan bağımsız değişkenler kalıncaya kadar tekrarlanmaktadır (Kalayc1, 2010, s.260).

Sağlıklı bir analiz sonucu elde etmek için regresyon modelinde çoklu bağlantı sorununun gösteren Tolerance değerinin 0,2 'den büyük ve VIF değerinin de 10 'dan küçük olduğu tespit edilmiş olup çoklu bağlantı sorunun olmadığı tespit edilmiştir. Bunun yanında regresyon modelinde 
otokorelasyon sorunun test eden Durbin Watson değerinin de 1,5 ile 2,5 arasında olduğu, dolayısıyla otokorelasyon sorununun olmadığı saptanmıştır. Etki analizi sonucunda elde edilen bulgular tablo 5, 6 ve 7' de sunulmuştur.

Tablo 5. A Kişilik Tipinin ile Kariyer ve Akademik Desteğinin Kariyer Uyum Yetenekleri Üzerindeki Etkisine İlişkin Regresyon Testi Bulguları

\begin{tabular}{|c|c|c|c|c|c|c|c|c|c|c|c|c|}
\hline \multirow{3}{*}{$\begin{array}{l}\text { BAĞIMSIZ DI } \\
\text { A Kişilik Tipi }\end{array}$} & \multicolumn{12}{|c|}{\begin{tabular}{c}
\multicolumn{2}{c}{ BAĞIMLI DEĞIȘKEN } \\
COPLAM KARİYER UYUM YETENEKLERİ (KUYÖ)
\end{tabular}} \\
\hline & \multicolumn{6}{|c|}{$\begin{array}{lll}\beta & p & \text { S.H. } \\
\end{array}$} & \multicolumn{6}{|c|}{ Regresyon Modelin Özeti } \\
\hline & & & ,435 & 000 & 03 & \multicolumn{7}{|c|}{$R^{2}=, 190 ;$ Adj. $R^{2}=, 187 ; F=65,517 ; p=, 000$} \\
\hline \multirow[t]{4}{*}{ KADÖ } & & & 186 & 002 & 02 & & $2^{2}=, 035$ & Adj. $R^{2}$ & $=031 ; \mathrm{F}$ & $=10,05$ & $p=000$ & \\
\hline & \multicolumn{12}{|c|}{ KARİYER UYUM YETENEKLERI BOYUTLARI } \\
\hline & \multicolumn{3}{|c|}{ Ilgi } & \multicolumn{3}{|c|}{ Kontrol } & \multicolumn{3}{|c|}{ Merak } & \multicolumn{3}{|c|}{ Güven } \\
\hline & $\beta$ & $p$ & S.H. & $\beta$ & $p$ & S.H. & $\beta$ & $P$ & S.H. & $\beta$ & $p$ & S.H. \\
\hline \multirow{2}{*}{ A Kişilik Tipi } & 241 & 000 & 046 & 414 & 000 & 043 & 285 &, 000 & 061 & 378 &, 000 & 045 \\
\hline & \multicolumn{2}{|c|}{$R^{2}=058$} & & \multicolumn{2}{|c|}{$\mathrm{R}^{2}=, 171$} & & \multicolumn{2}{|c|}{$R^{2}=, 081$} & & \multicolumn{2}{|c|}{$\mathrm{R}^{2}=, 143$} & \\
\hline \multirow[t]{3}{*}{$\begin{array}{l}\text { Regresyon } \\
\text { Modelin Özeti }\end{array}$} & \multicolumn{2}{|c|}{$\begin{array}{l}\text { Adj. } \mathrm{R}^{2}=, 055 \\
\mathrm{~F}=17,217 \\
p=, 000\end{array}$} & & \multicolumn{2}{|c|}{$\begin{array}{l}\text { Adj. } R^{2}=, 168 \\
F=57,927 \\
p=, 000\end{array}$} & & \multicolumn{2}{|c|}{$\begin{array}{l}\text { Adj. } R^{2}=, 078 \\
F=24,783 \\
p=, 000\end{array}$} & & \multicolumn{2}{|c|}{$\begin{array}{l}\text { Adj. } R^{2}=, 140 \\
F=46,734 \\
p=, 000\end{array}$} & \\
\hline & \multicolumn{3}{|c|}{ İlgi } & \multicolumn{3}{|c|}{ Kontrol } & \multicolumn{3}{|c|}{ Merak } & \multicolumn{3}{|c|}{ Güven } \\
\hline & $\beta$ & $p$ & S.H. & $\beta$ & $p$ & S.H. & $\beta$ & $p$ & S.H. & $\beta$ & $p$ & S.H. \\
\hline \multirow[t]{2}{*}{ KADÖ } & 202 & 001 & 025 & - & - & - & 250 &, 000 & 034 & - & - & - \\
\hline & \multicolumn{3}{|c|}{$\mathrm{R}^{2}=, 041$} & \multicolumn{3}{|l|}{$\mathrm{R}^{2}=$} & \multicolumn{3}{|c|}{$\mathrm{R}^{2}=, 063$} & \multicolumn{2}{|l|}{$\mathrm{R}^{2}=$} & \\
\hline $\begin{array}{l}\text { Regresyon } \\
\text { Modelin Özeti }\end{array}$ & \multicolumn{2}{|c|}{$F=11,886$} & & \multicolumn{2}{|c|}{ Adj. $R^{2}=$} & & $\begin{array}{l}\text { Adj. } \\
F=18 \\
p=00\end{array}$ & $\begin{array}{l}2=, 059 \\
703\end{array}$ & & $\begin{array}{l}\text { Adj. } 1 \\
\mathrm{~F}= \\
p=\end{array}$ & & \\
\hline
\end{tabular}

Not: KADÖ, A kişilik tipine sahip katılımcılar bağlamında test edilmiştir ( $\mathrm{N}=283)$.

Tablo 5'e göre hem A kişilik tipinin hem de KADÖ’nün toplam kariyer uyum yetenekleri ile kurulan regresyon modeli istatistiksel olarak anlamlı olduğu tespit edilmiştir $(p=, 000)$. Bulgulara göre A kişilik tipinin $(\beta=, 435$; $\mathrm{p}<0.05)$ ve KADÖ'nün $(\beta=, 186 ; p<0.05)$ toplam KUYÖ üzerinde anlamlı ve pozitif bir etkiye sahip olduğu tespit edilmiştir. Ancak burada A kişilik tipinin etkisi daha yüksek olduğu görülmektedir.

A kişilik tipinin kariyer uyum yetenekleriyle kurulan tüm regresyon modelleri istatistiksel olarak anlamlı olduğu tespit edilmiştir $(\mathrm{p}=, 000)$. İlgi $(\beta=, 241 ; \mathrm{p}<0.05)$, $\operatorname{kontrol}(\beta=, 414 ; \mathrm{p}<0.05)$, merak $(\beta=, 285 ; \mathrm{p}<0.05)$ ve güven $(\beta=, 378 ; p<0.05)$ üzerinde anlamlı ve pozitif bir etkiye sahiptir. $\beta$ kat say1ları dikkate alındığında A kişilik tipinin en fazla kontrol ve güven boyutlarını etkilediği görülmektedir.

Bu etki KADÖ bağlamında değerlendirildiğinde ise sadece ilgi ve merak boyutlarıyla kurulan regresyon modelinin anlamlı sonuç verdiği görülmektedir $(\mathrm{p}=, 000)$. Buna göre KADÖ, ilgi $(\beta=, 202 ; \mathrm{p}<0.05)$ ve merak 
$(\beta=, 250 ; \mathrm{p}<0.05)$ üzerinde anlamlı ve olumlu bir etkiye sahip olduğu görülmektedir. Bu sonuca göre KADÖ'nün en fazla merak boyutunu etkilediği söylenebilir.

Tablo 6. B Kişilik Tipinin ile Kariyer ve Akademik Desteğinin Kariyer Uyum Yetenekleri Üzerindeki Etkisine İlişkin Regresyon Testi Bulgular

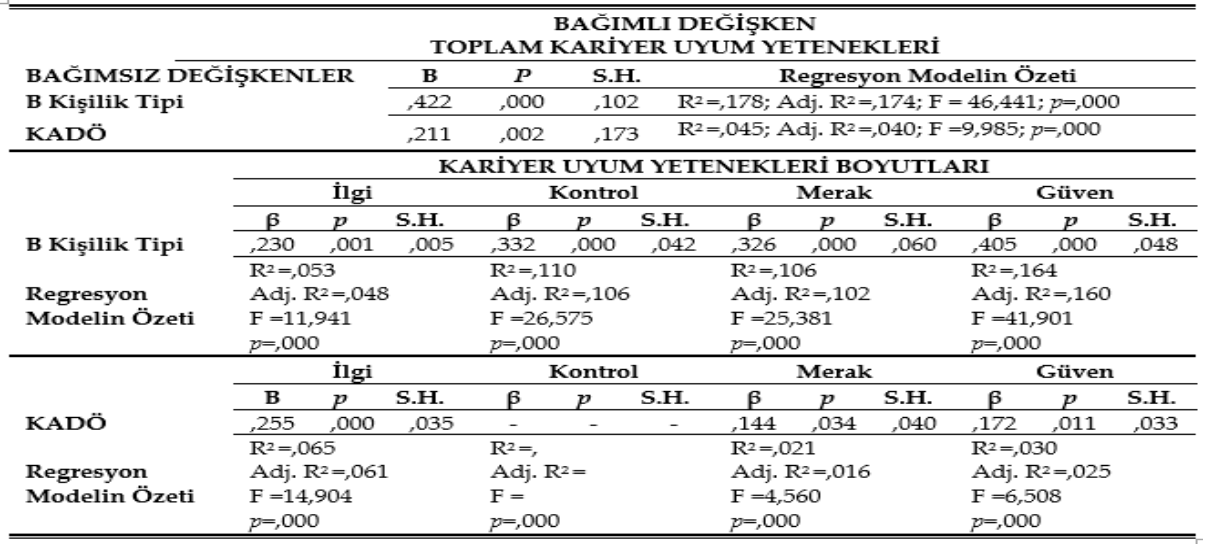

Not: KADÖ, B kişilik tipine sahip katılımcılar bağlamında test edilmiştir ( $\mathrm{N}=216)$.

Tablo 6'da verilen bulgular incelendiğinde hem B kişilik tipinin hem de KADÖ'nün toplam KUYÖ ile kurulan regresyon modelinin istatistiksel olarak anlamlı olduğu söylenebilir $(p=, 000)$. B kişilik tipinin $(\beta=, 422$; $p<0.05)$ ve KADÖ'nün $(\beta=, 211 ; p<0.05)$ toplam KUYÖ üzerinde anlamlı ve pozitif bir etkiye sahip olduğu ortaya konulmuştur. Buna göre kariyer uyum yeteneklerini B kişilik tipinin daha fazla etkilediği görülmektedir.

B kişilik tipinin kariyer uyum yetenekleriyle kurulan tüm regresyon modelleri istatistiksel olarak anlamlı olduğu tespit edilmiştir $(p=, 000)$. B kişilik tipinin; ilgi $(\beta=, 230 ; \mathrm{p}<0.05)$, kontrol $(\beta=, 332 ; \mathrm{p}<0.05)$, merak $(\beta=, 326$; $\mathrm{p}<0.05)$ ve güven $(\beta=, 405 ; \mathrm{p}<0.05)$ boyutları üzerinde anlamlı ve olumlu bir etkiye sahiptir. Ancak B kişilik tipi en fazla kontrol boyutunu etkilediği açıktır.

Bağımsız bir değişken olarak KADÖ’nün etkisi incelendiğinde sadece ilgi, merak ve güven boyutlarıyla kurulan regresyon modelinin istatistiksel olarak anlamlı olduğu görülecektir $(p=, 000)$. Buna göre bağımsız değişkenin ilgi $(\beta=, 255 ; \mathrm{p}<0.05)$, merak $(\beta=, 144 ; \mathrm{p}<0.05)$ ve güven $(\beta=, 172$; 
p<0.05) üzerinde anlamlı ve olumlu bir etkiye sahip olduğu tespit edilmiştir. Kariyer destek boyutu burada en fazla ilgi boyutunu etkilediği görülmektedir.

Tablo 7. Kariyer ve Akademik Desteğinin Kariyer Uyum Yetenekleri Üzerindeki Etkisine İlişkin Regresyon Testi Bulgularn

\begin{tabular}{|c|c|c|c|c|c|c|c|c|c|c|c|c|}
\hline \multirow{3}{*}{$\begin{array}{l}\text { BAĞIM } \\
\text { KADÖ }\end{array}$} & \multirow{3}{*}{\multicolumn{3}{|c|}{ DEĞİȘKENLER }} & & & & & & & & & \\
\hline & & & & \multirow{2}{*}{\multicolumn{2}{|c|}{$\begin{array}{cc}\beta & p \\
218 & , 000 \\
\end{array}$}} & \multirow{2}{*}{ S.H. } & \multicolumn{6}{|c|}{ Regresyon Modelin Özeti } \\
\hline & & & & & & & \multicolumn{6}{|c|}{$\mathrm{R}^{2}=, 048 ; \mathrm{Adj} . \mathrm{R}^{2}=, 046 ; \mathrm{F}=24,831 ; p=, 000$} \\
\hline & \multicolumn{12}{|c|}{ KARIYYER UYUM YETENEKLERİ BOYUTLARI } \\
\hline & \multicolumn{3}{|c|}{ İlgi } & \multicolumn{3}{|c|}{ Kontrol } & \multicolumn{3}{|c|}{ Merak } & \multicolumn{3}{|c|}{ Güven } \\
\hline & $\beta$ & $p$ & S.H. & $\beta$ & $p$ & S.H. & $\beta$ & $p$ & S.H. & $\beta$ & $p$ & S.H. \\
\hline KADÖ & 244 &, 000 & 021 & - & - & - & 220 &, 000 & 026 & 134 &, 003 &, 021 \\
\hline $\begin{array}{l}\text { Regresyon } \\
\text { Modelin } \\
\text { Özeti }\end{array}$ & \multicolumn{3}{|c|}{$\begin{array}{l}\mathrm{R}^{2}=, 060 \\
\mathrm{Adj} \cdot \mathrm{R}^{2}=, 058 \\
\mathrm{~F}=31,472 \\
p=, 000\end{array}$} & \multicolumn{2}{|c|}{$\begin{array}{l}\mathrm{R}^{2}= \\
\mathrm{Adj} \cdot \mathrm{R}^{2}= \\
\mathrm{F}= \\
p=, 000\end{array}$} & & \multicolumn{3}{|c|}{$\begin{array}{l}\mathrm{R}^{2}=, 048 \\
\mathrm{Adj} . \mathrm{R}^{2}=, 046 \\
\mathrm{~F}=25,275 \\
p=, 000\end{array}$} & \multicolumn{3}{|c|}{$\begin{array}{l}\mathrm{R}^{2}=, 018 \\
\mathrm{Adj} \cdot \mathrm{R}^{2}=, 016 \\
\mathrm{~F}=9,124 \\
p=, 000\end{array}$} \\
\hline
\end{tabular}

Not: Tüm Örneklem teste tabi tutulmuştur ( $\mathrm{N}=499)$.

Tablo 7' de verilen bulgulara göre KADÖ'nün toplam KUYÖ ile kurulan regresyon modelinin istatistiksel olarak anlamlı olduğu saptanmıştır $(\mathrm{p}=, 000)$. KADÖ'nün KUYÖ $(\beta=, 218 ; \mathrm{p}<0.05)$ üzerinde anlamlı ve pozitif bir etkiye sahiptir. Bunun yanında boyutlar bağlamında bu etki değerlendirildiğinde de ilgi, merak ve güven boyutlarıla kurulan regresyon modellerinin istatistiksel olarak anlamlı olduğu görülecektir $(p=, 000)$. KADÖ'nün; ilgi $(\beta=, 244 ; \mathrm{p}<0.05)$, merak $(\beta=, 220 ; \mathrm{p}<0.05)$ ve güven $(\beta=, 134$; $p<0.05)$ boyutları üzerinde anlamlı ve olumlu bir etkiye sahip olduğu tespit edilmiştir. Ancak burada KADÖ en fazla ilgi boyutunu etkilediği görülmektedir.

\section{Tartışma ve Sonuç}

Kariyer uyum yetenekleri bireylerin artan mesleki geçişlerin zorluğunu kolaylaştıracak potansiyel olumlu bir zihinsel ve duygusal yönüdür. Buradan hareketle bu çalışma öğrencilerin iş hayatına atılmadan önce geleceklerini düşünmelerini, ilgili iş alanlarını, istihdam olanaklarını ve kendilerine olan güvenlerini ölçmeye ve bunu etkileyen kişilik yapısı ile kariyer ve akademik desteğin düzeyini ortaya koymaya çalışmaktadır.

Kariyer uyum yetenekleri yüksek olan öğrenciler iş ararken sadece kendilerine daha fazla güvenmekle kalmayıp aynı zamanda mezuniyet 
sonrası işe alınma olasılıkları da yükselmektedir. Bu nedenle öğrencilerin iş ararken daha rahat, kariyer kararları verirken daha etkili ve genel olarak kariyerleri konusunda daha yetkin ve iyimser olmaları için danışmanlarına önemli görevler düşmektedir (Duffy, Douglass and Autin, 2015, s. 47).

Öğrenciler için önemli bir destek kaynağının danışmanlar olduğu görülmektedir. Nitekim öğrenci kitlesi zamanın büyük çoğunluğunu okulda, öğretim üyeleriyle sıklıkla etkileşime girerek geçirmektedir (Metheny, McWhirter and O'Neil, 2008, s. 220). Daha önce yapılan çalışmalar, danışman desteğinin olumlu beklentileri ve iyimserlik düzeyini olumlu etkilediği tespit edilmiştir. Danışman desteği ile bireyin kariyer başarı beklentileri arasında pozitif bir ilişkinin olduğu saptanmıştır. Özellikle, danışman tutumları ve davranışları öğrencilerin kariyer gelişimi ile ilgili olumlu beklentilerini güçlendirmektedir (Suldo vd., 2009, s. 69). Öğretmen desteği kişinin özgüvenini güçlendirmektedir (Garcia, Restubog, Bordia, Bordia and Roxas, 2015, s. 12).

Kariyer danışmanlarının, eğitimcilerin ve psikologların; ergenlerin mevcut ve gelecekteki kariyer hedeflerine yönelik daha uyumlu, dirençli ve proaktif yaklaşımlar geliştirmelerine yardımcı olmaları, günümüzde daha çok ihtiyaç duyulmaktadır (Garcia vd., 2015, s. 17). Öyle ki Julien (1999) gençlerin \%60'ı kariyer kararı alabilmek için gereken bilgileri nerede bulacağını bilmediğini tespit etmiştir. Bu durum şüphesiz bir işe yerleşememek veya istediği bir kariyer planlamasını yapamamak gibi istenmeyen bir durumla sonuçlanabilmektedir (Creed, Fallon and Hood, 2009, s. 18).

Elde edilen bulguların sonuçlarına bakıldığında kariyer uyum yeteneklerinde en yüksek ortalama kontrol boyutuna ait olduğu görülmektedir. Ondan sonra güven, ilgi ve merak gelmektedir. Taş (2018), Yeşiltaş ve arkadaşları (2014) ve Kanten (2012) yaptıkları çalışmalarında bu sıralamanın güven, kontrol, ilgi ve merak şeklinde dizildiğini tespit etmişlerdir. Ortaya konan bu sonuçlar bu çalışmanın sonuçlarıyla birebir örtüşmediği, bu çalışmada kontrol boyutuna daha fazla puan verildiği görülmektedir. Öğrencilerin kendi kariyerlerine katkı sağlayacak faaliyetlerle ilgilendiklerini, gelecekleri hakkında nispeten iyimser davrandıklarını, kendi kararlarını kendilerinin vermeye çalıştıklarını, kendilerine güvenmeye ve so- 
rumluluk almaya başladıklarını ortaya koymaktadır. Lisans öğrencilerinin kontrol düzeyinin lisansüstü öğrencilerinkinden daha yüksek olduğu da önemli bir bulgular arasındadır. Diğer yandan kariyer ve akademik destek boyutlarına nispeten daha az puan verildiği saptanmıştır. $\mathrm{Bu}$ bulgu, öğrencilerin gerek danışmanlarından gerekse diğer öğretim üyelerinden aldıkları destek düzeyinin düşük olabileceğine işaret etmektedir. Bu çalışmada da A kişilik tipine sahip bireylerde kariyer desteğinin; B kişilik tipinde ise akademik desteğinin kariyer uyum yeteneklerini etkilemediği saptanmıştır.

Kişilik değişkeni, toplam kariyer uyum yetenekleriyle ve tüm boyutlarıyla yüksek düzeyde, anlamlı ve pozitif bir ilişkisinin olduğu tespit edilmiştir. Ancak bu ilişki en fazla toplam kariyer uyum yeteneğiyle, ikinci sırada ise güven boyutuyla gerçekleşmiştir. Nitekim yapılan önceki çalışmaların bazılarında kişilik özellikleri ve kariyer memnuniyeti arasında pozitif yönlü ve anlamlı bir ilişkinin varlığı saptanmıştır (Yavaş, 2018, s.93). Bunu yanında kariyer uyumluluğu ile A ve B kişilik yapısı arasında anlamlı ilişkiler de saptanmıştır. Bireyin kişiliğini, kariyer uyumluluğunu ve kariyer uyumluluğunun alt bileşenlerini anlamak, bir kişinin kariyer kararını ve sonuç olarak bu pozisyondaki memnuniyetini etkileyebileceği ileri sürülmektedir (Norris, 2016, s.41-45).

Benzer şekilde hem kariyer ve akademik destek değişkeninin kariyer uyum yetenekleri ve boyutları (kontrol hariç) arasında yüksek, anlamlı ve pozitif bir ilişkinin varlığı saptanmıştır. Kişilik yapısı bağlamında etki testi sonuçları değerlendirildiğinde hem A hem de B kişilik tipinin toplam kariyer uyum yetenekleri üzerinde anlamlı bir etkiye sahip olduğundan dolayı $\mathrm{H} 1$ ve $\mathrm{H} 2$ desteklenmiştir. Ancak A kişilik yapısı en fazla toplam kariyer uyum yetenekleri değişkenini, ondan sonra etki derecesi büyüklügüne göre kontrolü, güveni, merak ve ilgiyi etkilemektedir. B kişilik yapısı, en fazla güven olmak üzere kontrol, merak ve ilgi boyutlarını önemli ve olumlu düzeyde etkilediği tespit edilmiştir. Fakat etki derecesine bakıldığında A kişilik yapısı bu değişkenleri daha fazla etkilediği görülmektedir. Bunun yanında, A tipi kişiliğe sahip bireylerde kariyer ve akademik desteğin toplam kariyer uyum yeteneklerini anlamlı ve olumlu etkilemektedir. B nedenle H3 desteklenmiştir. Fakat bu etki sadece ilgi ve merak boyutları üzerinde görülmekte olup en fazla merak boyutunu etkilediği saptanmıştır. Diğer taraftan B kişilik yapısına sahip bireylerde de kariyer 
ve akademik destek değişkenin toplam kariyer uyum yeteneğini olumlu etkilediği tespit edilmiştir. Dolayısıyla H4'ün desteklendiği söylenebilir. Boyutlar bağlamında ise sadece ilgi, merak ve güven faktörlerinin anlamlı ve olumlu etkilendiği saptanmıştır. Burada en fazla etki ilgi boyutunda gerçekleşmiştir.

Bir bütün olarak kariyer ve akademik desteğin toplam kariyer uyum yeteneklerini anlamlı ve pozitif yönde etkilediği tespit edildiğinden dolayı H5 de kabul edilmiştir. Bunun yanında; ilgi, merak ve güven boyutlarının olumlu etkilendiği saptanmıştır. Ancak burada en fazla ilgi boyutunun etkilendiği görülmektedir.

Genel olarak A kişilik tipine sahip bireylerin sorumluluk alan, kendi kararlarını alabilen, inisiyatif kullanmak isteyen ve otokontrol mekanizmasına sahip oldukları düşünüldüğünde bu sonucun şaşırtıcı olduğu söylenemez. Nitekim A kişilik tipinin proaktiflik ve dişadönüklük ile ilişkili olduğuna dair bulgular da mevcuttur (Norris, 2016, s.41-45; Yavaş, 2018, s.93). Öğrencilerin kariyer planı yapma, istihdam olanaklarını araştırma ve mesleki tercihi yapma konusunda bağımsız olmak isteyebilirler. Ancak kendi kişilik özelliklerinin SWOT analizini yapma ve kendileri için en uygun mesleği tercih etme konusunda yetersiz olabilirler. Bu noktada danışmanın yol göstericiliği önemli bir etken olabilir. Nitekim bir takım çalışmalarda akademik destek ve danışmanlık, öğrencilerin motivasyonunu ve başarısını tetiklediği tespit edilmiştir (Hughes, Wu, Kwok, Villarreal and Johnson, 2011, s.445). Hatta öğrencilerin danışmanlarından aldıkları destek nedeniyle okula bağlılıklarının da arttı̆̆ı görülmektedir (Reed ve Wexler, 2014, s.188). Bu bulgu, gelecek yönelimi güçlü olan öğrencilerin kariyer planlama faaliyetlerine yatırım yapma ve okulda daha iyi performans gösterme eğiliminde olduğunu göstermektedir. Kariyer ilgisi en önemli uyum yeteneği olarak görülmektedir. Çünkü bir öğrencinin kendini geleceğe yansıtma kapasitesini ortaya koymakta ve kişisel güçlü yanlarını en iyi şekilde karşılayan bir mesleki benliğe atıf yapmaktadir (Negru-Subtirica ve Pop, 2016, s.167-168). Negru-Subtirica ve Pop, yaptıkları çalışmada öğrencilerin akademik başarının kariyerleri konusunda kendilerine duydukları güven ile pozitif yönlü ilişki tespit etmişlerdir. Diğger yandan danışman desteğinin öğrencinin kariyer gelişiminde küçük ama önemli bir rol oynayabildiği ifade edilmektedir. Perry, Liu and Pabian (2010, s.275) danışman desteğinin kariyer uyumluluğuna eşsiz ve 
anlamlı bir katkı yaptığını tespit etmişlerdir. Karacan Özdemir (2016), iyimserliğin genel öz-yeterlilik inancı aracılığıla kariyer uyum yetenekleri üzerinde dolaylı bir etkiye sahip olduğunu saptamıştır.

\section{Öneriler}

Her şeyden evvel fakültelerde öğrencilerin kariyer gelişimiyle ilgili profesyonel olarak yardım alabilecekleri "Kariyer Danışmanlığı ve Rehberlik" adında bir birimin olması son yıllarda ciddi bir ihtiyaç haline gelmiştir. Öğrencilerin geleceğe önemli düzeyde karamsar baktığı birçok öğrenciyle yapılan görüşmeden sonra anlaşılmıştır. Bu bağlamda ders müfredatlarında, öğrencilerin farkındalık kazanması için "Kariyer Gelişimi" veya "Kariyer Planlaması" isimli zorunlu bir ders eklenebilir. Akademik danışmanlar öğrencilerle mümkün olduğunca birebir veya küçük gruplar halinde mentorlük edebilirler. Danışmanlar, öğrencilerin stresini azaltmak için öğrencilere destek olabilir ve rehberlik edebilir. Öğrencilerin problem çözme noktasında önemli becerileri öğrenemedikleri için yardıma ihtiyaç duyduğu gözlenmektedir. Danışmanlar burada, öğrencilerin planlı ve etkili kararlar vermelerini sağlayarak kaygı ve karamsarlık düzeylerini azaltabilirler. Her bireyin sahip olduğu kültürel değerleri ve kişilik özellikleri meslek seçiminde önemli rol oynadığı aşikârdır. O nedenle kariyer danışmanları, öğrencilere yol gösterirken bireysel ve kültürel değerleri göz önünde bulundurmalıdır. Öğrencilerin kişilik özellikleri ve bireysel değerleri incelendikten sonra uygun bir mesleğe kanalize edilmelidir.

Kariyer uyum yeteneklerini etkileyen diğer faktörler üzerinde yapılacak gelecekteki araştırmalar, bireylerin kariyer geçişlerini olabildiğince düzgün hale getirmenin nasıl sağlanacağını anlamak için önem arz etmektedir. Kariyer uyumluluğunu etkileyen diğer değişkenlerin belirlenmesi, genellikle stresin eşlik ettiği değişim aşamalarında çalışan tatminini artırmaya yardımcı olabilir. B nedenle iş değişiminin yaygın olduğu bir zamanda, kariyer uyumluluğunu etkileyen veya güçlendiren daha fazla araştırmalar büyük bir değer taşımaktadır. 


\title{
EXTENDED ABSTRACT
}

\section{The Effect of Personality Type and Career and Academic Support on Career Adaptability: A Field Research}

\author{
Mehmet Ali Taş - Mehmet Özmen \\ Burdur Mehmet Akif Ersoy University
}

Along with environmental factors, one of the most influential factors on career choice is undoubtedly the personality trait that shows little change over time. Therefore, the preferred profession and personality structure should be compatible. If the occupation meets the needs and values of the person, the personality and the work become harmony. In addition, if the skills required by the job are available in that person, harmony develops between the person and the job. In Turkey, the young individuals recently graduated requirement arises concerns on a job that is compatible with personality. In particular, the increasing number of graduates in recent years and the excess supply of labor in this context increase this concern. Since university graduates are newly acquainted with these stages, the job search for them is often full of unexpected difficulties. In this context, it is suggested that career adaptability skills will increase the self-regulation capacity of university graduates in job search and therefore the probability of employment.

It is seen that, it is important for individuals to review their career plans considering their personality traits, to get support from their academic advisors and to develop their career adaptability skills. Since career development involves education, students begin to work on their careers before entering a real working life. Therefore, it is seen that students' future work lives, personality traits, career compatibility and academic achievements are mutually and actively linked throughout their student life. From this point of view, it should not be forgotten that personality trait is a key element when considering career development. 
The choice of profession in early childhood reveals personality in many ways. In fact, the chosen profession; it shows the characteristics of the personality, the student's knowledge, abilities, desires and interests. Most university students experience significant problems in making a career decision. At this point, it can be said that the support of academics and family is a turning point for the students' future. It is an important responsibility of academic advisors to guide students towards their professional preferences at a young age and to channel them to a career path according to personality traits. It is known that the role of consultants in this issue will shape the future life of the students. As a result of the effective and efficient consultancy process, it is seen that the positive opinions about the professional future are strengthened.

The aim of this study is to investigate the effect of personality type on career adaptabilities of students. The second important variable affecting career adaptation skills is the role of educators' career and academic support. In addition, the role of career and academic support in the context of A and B type personality differences was investigated.

The population chosen in this study consists of undergraduate and master students of Burdur Mehmet Akif Ersoy University in the fall semester of 2018-2019 academic year. The reason for choosing this sample is that, it has the opportunity to choose many jobs after graduation and has a wide range of careers. A questionnaire was used to collect data from the participants.

According to the findings obtained from the descriptive analysis, 330 (66.1\%) of the participants were female and 169 (33.9\%) were male. In addition, $283(56.7 \%)$ of the participants had A personality type and 216 (43.3\%) had B personality type.

Counselors seem to be an important source of support for students. As a matter of fact, it was found that there was a positive relationship between the support of counselor and individual's career success expectations. It is seen that the highest average in career adaptability skills belongs to the control dimension. Then comes confidence, concern and curiosity. These results show that students are interested in activities that contribute to their careers, they are relatively optimistic about their future, they try to make their own decisions, they start to trust themselves and 
take responsibility. It is also important that the control level of undergraduate students is higher than that of master students. On the other hand, it was found that career and academic support dimensions were given less points. This finding indicates that the level of support that students receive from both their advisors and other educators may be low.

In this study, it was found that career support did not increase career adaptability in individuals with personality type A and academic support in personality type B. It was found that personality variable had a high, significant and positive relationship with career adaptabilities. Similarly, there was a high, significant and positive relationship between career adaptabilities (excluding control) of both career and academic support variable. Personality type $A$ and $B$ have a significant effect on total career adaptabilities.However, the personality type of $\mathrm{A}$ affects the total career adaptabilities at most. After that, the degree of influence affects control, confidence, curiosity and concern according to the size. It was determined that B personality type positively affected confidence, control, curiosity and concern dimensions. However, when the effect level is considered, personality type A affects these variables more. In addition, in individuals with A personality type, career and academic support has a significant and positive effect on total career adaptabilities. However, this effect was observed only on the dimensions of concern and curiosity and it was found that the curiosity dimension was affected the most. On the other hand, it was found that career and academic support variable positively affect career adaptation ability in individuals with $\mathrm{B}$ personality type structure. In terms of dimensions, only concern, curiosity and confidence factors were found to be significantly affected. The greatest effect was achieved in the concern dimension.

First of all, the existence of a unit called "Career Counseling and Guidance" in the faculties where students can get professional help about career development has become a serious need in recent years. A compulsory course called "Career Development" or "Career Planning" can be added in order to raise awareness among the students in the curriculum. Academic advisors can mentor students as much as possible. 


\section{Kaynakça / References}

Adena, D., Young-Jones, T., Burt, D., Dixon, S. ve Hawthorne, M. J. (2013). Academic advising: Does it really impact student success?. Quality Assurance in Education, 21(1), 7-19.

Aktaş, A. M. (2001). Bir kamu kuruluşunun üst düzey yöneticilerinin iş stresi ve kişilik özellikleri. Ankara Üniversitesi SBF Dergisi, 56(4), 25-43.

Arıkan, Ç. ve Aktaş, A. (1998). Kişilik özellikleri ile aile ve çevre yaşantısının kalp hastalığının oluşumuna etkisi. XXIV. Ulusal Psikiyatri ve Nörolojik Bilimler Kongresinde Sunulan Bildiri, Tarih, Yer.

Autin, K. L., Douglass, R. P., Duffy, R. D., England, J. W. ve Allan, B. A. (2017). Subjective social status, work volition and career adaptability: A longitudinal study. Journal of Vocational Behavior, 99, 1-10.

Barutçu, İ. (2004). Stratejik insan kaynakları yönetimi. İstanbul: Kariyer Yayınc1lik.

Bingöl, D. (2013). İnsan kaynakları yönetimi. İstanbul: Beta Basım Yayım.

Brennan, G. M. (1989). A study of type $a$ and type b personality and burnout in nurses. Master Thesis, San Jose State University, San Jose.

Bullock, E. E. , Reardon, R. C. ve Lenz, J. G. (2007). Planning good academic and career decisions. Fostering Student Success in the Campus Community. San Francisco: Jossey - Bass.

Bullock-Yowell, E., McConnell, A. E. ve Schedin, E. A. (2014). Decided and unde-cided students: Career self-efficacy, negative thinking, and decision-making difficulties. NACADA Journal, 34, 122-34.

Buyukgoze-Kavas, A., Duffy, R. D., ve Douglass, R. P. (2015). Exploring links between career adaptability, work volition, and well-being among Turkish students. Journal of Vocational Behavior, 90, 122-131.

Creamer, D. G. ve Creamer, E. G. ( 1994 ). Practicing developmental advising: Heoretical contexts and functional applications. NACADA Journal, 14 (2), 17-24.

Creed, P. A., Fallon, T. ve Hood, M. (2009). The relationship between career adaptability, person and situation variables, and career concerns in young adults. Journal of Vocational Behavior. 74(2), 219-229.

Crisp, G. ve Cruz, I. (2010). Confirmatory factor analysis of a measure of mentoring among undergraduate students attending a hispanic serving institution. Journal of Hispanic Higher Education. 9(3), 232-244. 
Crisp, G. (2009). Conceptualization and initial validation of the college student mentoring scale (CSMS), Journal of College Student Development. 50(2), 177-194.

Cunningham, K. ve Smothers, A. (2014). The effect of career cruising on the self-efficacy of students deciding on majors. NACADA Journal. 34(2), 16-25.

Çetin, F. ve Basım, N., (2014). Örgütte bireysel farklıklar, kişilik ve değerler. (Edt. Ü. Sığrı ve S. Gürbüz), Örgütsel Davranış, İstanbul: Beta Yayınlar.

Duffy, R. D., Douglass, R. P. ve Autin, K. L. (2015). Career adaptability and academic satisfaction: Examining work volition and self efficacy as mediators, Journal of Vocational Behavior, 90, 46-54.

Durna, U. (2004). Stres, a ve b tipi kişilik yapısı ve bunlar arasındaki ilişki üzerine bir araştırma. Yönetim ve Ekonomi: Celal Bayar Üniversitesi İktisadi ve İdari Bilimler Fakültesi Dergisi. 11(1), 191-206.

Ender, S. C. ve Wilkie, C. J. (2000), Advising students with special needs. Academic Advising: Comprehensive Handbook, 1, 118-143.

Erden vd., (2012), A tipi kişilik özelliği ile işkoliklik arasındaki ilişkide iş taleplerinin rolü. 20. Ulusal Yönetim ve Organizasyon Kongresi Bildiriler Kitabı içinde (s.169-173), Tarih, Dokuz Eylül Üniversitesi İşletme Fakültesi, İzmir.

Erdoğmuş, N., (2003), Kariyer geliştirme, kuram ve uygulama. Ankara: Nobel Akademik Yayıncilı.

Ertürk, M., (2011). İnsan kaynakları yönetimi. İstanbul: Beta Basım Yayım.

Friedman, M. ve Rosenman, R. H. (1959). Association of specific overt behavior pattern with blood and cardiovascular findings, blood cholesterol level, blood clotting time, incidence of arcus senilis, and clinical coronary artery disease. Journal of the American Medical Association. 169(12), 286-1296.

Garcia, P. R. J. M., Restubog, S. L. D., Bordia, P., Bordia, S., and Roxas, R. E. O. (2015). Career optimism: The roles of contextual support and career decision-making self-efficacy. Journal of Vocational Behavior, 88, 10-18.

Gordon, V. N. (2006). Career advising: An academic advisor's guide. San Francisco: Jossey -Bass.

Gök, E ve Aydın, B. (2017). Yükseköğretim öğrenci mentörlük ölçeği geliştirme yolunda pilot bir çalışma. Kırıkkale Üniversitesi Sosyal Bilimler Dergisi, 7(1), 107-120. 
Guan, Y., Deng, H., Sun, J., Wang, Y., Cai, Z., Ye, L., ve Li, Y. (2013). Career adaptability, job search self-efficacy and outcomes: A three-wave investigation among chinese university graduates. Journal of Vocational Behavior. 83(3), 561-570.

Gümüştekin, G. E. ve Gültekin, F. (2009). Stres kaynaklarının kariyer yönetimine etkileri. Dumlupinar University Journal of Social Sciences, 23, 147158.

Güney, S. (2014). İnsan kaynakları yönetimi. Ankara: Nobel Akademik Yayıncllik

Güney, S. (2017). Yüksek lisans doktora yeterlilik ve doçentlik sinavlarn için yönetim ve organizasyon el kitabl, 2. Baskı, Ankara: Nobel Akademik Yayıncılık

Güney, S. (2018). Davranış bilimler. 11. Baskı, Ankara: Nobel Akademik Yayıncilik

Gürbüz, S. ve Şahin, F. (2015). Sosyal bilimlerde araştırma yöntemleri. Ankara: Seçkin Yayıncılık.

Harry, N. ve Coetzee, M. (2013). Sense of coherence, career adaptability and burnout of early-career black staff in the call centre environment. $S A$ Journal of Industrial Psychology, 39(2), 1-10.

Hughes, J. N., Wu, J. Y., Kwok, O. M., Villarreal, V. ve Johnson, A. Y. (2011). Foundations of career advising. The handbook of Career Advising. 1-18.

İlhan, M., ve Çetin, B. (2014). LISREL ve AMOS programları kullanılarak gerçekleştirilen yapısal eşitlik modeli (yem) analizlerine ilişkin sonuçların karşılaştırılması. Eğitimde ve Psikolojide Ölçme ve Değerlendirme Dergisi, 5(2), 26-42.

Kalaycı, Ş. (2010). SPSS uygulamalı çok değişkenli istatistik teknikleri. Ankara: Asil Yayın Dağıtım.

Kanten, S.(2012). Kariyer uyum yetenekleri ölçeği: Geçerlilik ve güvenilirlik çalışması. Süleyman Demirel Üniversitesi Sosyal Bilimler Enstitüsü Dergisi, 16, 191-205.

Karacan-Ozdemir, N. ve Yerin-Guneri, O. (2017). The factors contribute to career adaptability of high-school students. Eurasian Journal of Educational Research, 67, 183-198.

Kocagöz, E. ve Dursun, Y. (2010). Algılanan davranışsal kontrol, ajzen'in teorisinde nasıl konumlanır? Alternatif model analizleri. Karamanoğlu Mehmetbey Üniversitesi Sosyal ve Ekonomik Araştırmalar Dergisi, 2, 139152. 
Kuhn, T., Gordon, V. N. ve Webber, J. ( 2006 ). The Advising and Counseling Continuum: Triggers for Referral. NACADA Journal, 26(1), 24-31.

Kunnanatt J.W. (2003). Type A Behavior Pattern and Managerial Performance: A Study among Bank Executivesin India. International Journal of Manpower. 24(6), 720-734.

Lynch, J. ve Lungrin, T. (2018). Integrating academic and career advising toward student success. New Directions For Higher Education. 184, 6979.

Marcionetti, J. ve Rossier, J. (2017). The mediating impact of parental support on the relationship between personality and career indecision in adolescents. Journal of Career Assessment, 25(4), 601-615.

McKenna, C. W. (2010). The relationship of type $a$ and type $b$ personalities and disease management effectiveness on the perceived stress and self-efficacy of people with type 1 and type 2 diabetes. Doctoral Dissertation, Walden University, Minneapolis, Minnesota.

McShane, S. L. ve Von Glinow, M. A. (2016). Örgütsel davranış. (Çev. A. Günsel ve S. Bozkurt), Ankara: Nobel Yayıncilik.

Metheny, J., McWhirter, E.H., ve O'Neil, M.E. (2008). Measuring perceived teacher support and its influence on adolescent career development. Journal of Career Assessment. 16(2), 218-237.

Mortimer, J. T., Zimmer-Gembeck, M. J., Holmes, M. ve Shanahan, M. J. (2002). The process of occupational decision making: Patterns during the transition to adulthood. Journal of Vocational Behavior, 61(3), 439465.

Negru-Subtirica, O. ve Pop, E. I. (2016). Foreshadowing 1dentities: The relation between achievement goals and educational identity in a sample of romanian emerging adults. Cognitie, Creier, Comportament/Cognition, Brain, Behavior. 17(1), 1-14.

Negru-Subtirica, O. ve Eleonora, I. P. (2016). Longitudinal links between career adaptability and academic achievement in adolescence. Journal of Vocational Behavior, 93, 163-170.

Nora, A. ve Crisp, G. (2007). Mentoring students: Conceptualizing and validating the multi-dimensions of a support system. Journal of College Student Retention: Research, Theory \& Practice. 9(3), 337-356.

Norris, C. F. (2016). The relationship between personality traits and career adaptability. Master of Arts Degree, M.A., Southern Illinois University Carbondale. 
Onay, M. ve Zel, U. (2011). Kişi-kültür uyumunun kariyer planlaması üzerindeki etkileri. Doğuş Üniversitesi Dergisi, 12(2), 265-278.

Özdevecioğlu, M. ve M. S. A. (2005). Organizasyonlarda sabotaj: Türleri, amaçları, hedefleri ve yönetimi. Cumhuriyet Üniversitesi İktisadi ve İdari Bilimler Dergisi, 6(1), 95-109.

Özkalp, E. (2015). Ünite 2, Örgütsel davranışa giriş ve yöntem. (A. Çiğdem Kırel ve O. Ağlargöz haz.), Örgütsel Davranış, (3. Bsk.) Ankara: Anadolu Üniversitesi Yayınları.

Papatya, G., Papatya, N. ve Hamşığlu, A. B. (2016). Girişimci yönlülük, içgirişimcilik ve işletme performans ilişkisi: Türkiye tekstil sektörü işletmelerinde bir Araştırma. Hacettepe Üniversitesi İktisadi ve İdari Bilimler Fakültesi Dergisi, 34(4), 19-48.

Perry, J. C., Liu, X. ve Pabian, Y. (2010). School Engagement as A Mediator of Academic Performance Among Urban Youth: The Role of Career Preparation, Parental Career Support, and Teacher Support. The Counseling Psychologist. 38(2), 269-295.

Potgieter, M. (2014). The relationship between career adaptability and employee engagement amongst employees in an insurance company. Doctoral Dissertation, University of South Africa.

Reed, D. K. ve Wexler, J. (2014). Our teachers... don't give us no help, no nothin: Juvenile offenders' perceptions of academic support. Residential Treatment for Children and Youth, 31(3), 188-218.

Robbıns, S. ve Judge, T. A. (2015). Örgütsel davranış. (Çev. İ. Erdem), Ankara: Nobel Yayınları.

Roeser, R.W., Eccles, J.S. ve Sameroff, A.J. (2000). School as a context of early adolescents' academic and social-emotional development: A Summary of research findings. The Elementary School Journal. 100(5), 443471.

Savickas, M. L. (1997). Career adaptability: An integrative construct for lifespan, life-space theory. The Career Development Quarterly. 45(3), 247259.

Savickas, M. L. ve Porfeli, E. J. (2012). Career adapt-abilities scale, construction, reliability, and measurement equivalence across 13 countries. Journal of Vocational Behavior, 80(3), 661-673.

Schnabel, K.U., Alfeld, C., Eccles, J.S., Köller, O. ve Baumert, J. (2002). Parental influence on students' educational choices in The United States and 
Germany: Different ramifications - same effect?, Journal of Vocational Behavior, 60, 178-198.

Seçkin, M., Aypay, A. ve Apaydın, Ç. (2014). Lisansüstü eğitim alan öğrencilerin akademik danışmanlık hakkındaki görüşleri. Journal of Higher Education \& Science/Yüksekögretim ve Bilim Dergisi. 4(1), 28-35.

Soysal, A. (2008). Çalışma yaşamında kişilik tipleri: Bir literatür taraması. Çimento İşveren Dergisi, 1(2), 24-19.

Suldo, S.M., Friedrich, A.A., White, T., Farmer, J., Minch, D. ve Michalowski, J. (2009). Teacher support and adolescents' subjective well-being: A mixed-methods investigation. School Psychology Review, 38(1), 67-85.

Super, D. E. (1980). A life-span, life-space approach to career development. Journal of Vocational Behavior, 16(3), 282-298.

Šverko, I., ve Babarović, T. (2016). Integrating personality and career adaptability into vocational interest space. Journal of Vocational Behavior, 94, 89-103.

Şahin, N. H., Güler, M. ve Basım, H. N. (2009). A tipi kişilik örüntüsünde bilişsel ve duygusal zekânın stresle başa çıkma ve stres belirtileri ile ilişkisi. Türk Psikiyatri Dergisi, 20(3), 243-254.

Şimşek, M. Ş., Çelik, A. ve Akgemci, T. (2016). Davranış bilimlerine giriş ve örgütlerde davranış. Konya: Eğitim Kitabevi.

Taş, M.A. (2018). Kültürel değgerler, psikolojik sermaye ve kariyer uyum yeteneği ilişkisine dair bir saha araştırması. Yüksek Lisans Tezi, Mehmet Akif Ersoy Üniversitesi, Sosyal Bilimler Enstitüsü, 2018.

Taşlıyan, M., Arı, N. Ü. ve Düzman, B. (2011). İnsan kaynakları yönetiminde kariyer planlama ve kariyer yönetimi: İ̈BF öğrencileri üzerinde bir alan araştırması. Organizasyon ve Yönetim Bilimleri Dergisi, 3(2), 231241.

Thorne-Figueroa, J. M. (2010). The relationship between personality types $a$ and $b$ and academic dishonesty of undergraduate and graduate students. Doctoral Dissertation, Walden University, Minneapolis, Minnesota.

Tolentino, L. R., Garcia, P.R.J.M., Lu, V. N., Restubog, S. L. D., Bordia, P. ve Plewa, C. (2014). Career adaptation: The relation of adaptability to goal orientation, proactive personality and career optimism. Journal of Vocational Behavior, 84(1) 39-48. 
Turban, D. B., Stevens, C. K. ve Lee, F. K. (2009). Effects of conscientiousness and extraversion on new labor market entrants'job search: the mediating role of metacognitive activities and positive emotions. Personnel Psychology, 62(3), 553-573.

Ünsal, P. (2014). Kariyer gelişim kuramları ve kariyer danışmanlı̆̆̆. Ankara: Nobel Yayınları.

Walters-Archie, A. (2018). Academic support for online students in the English-speaking Caribbean at the University of The West Indies Open Campus. Journal of Further and Higher Education, 42(6), 868-878.

Wanberg, C. R., Zhang, Z. ve Diehn, E. W. (2010). Development of the getting ready for your next job inventory for unemployed individuals. Personnel Psychology, 63(2), 439-478.

Yavaş, Ö. (2018). Kişilik özellikleri ve çalş̧anların kariyer gelişiminin kariyer memnuniyetleri üzerine etkisi ve bir araştırma. Yüksek Lisans Tezi, Yıldız Teknik Üniversitesi. İstanbul.

Yeşiltaş, M., Akdă̆, G., Çeken, H. ve Gürlek, M. (2014). Kariyer uyum yetenekleri turizm sektörüne bağlllı̆̆1 etkiler mi: Lisans düzeyinde turizm eğitimi alan öğrencilere yönelik bir uygulama. 15. Ulusal Turizm Kongresi Bildiriler Kitabl, Tarih: Ankara.

Yousefi, Z., Abedi, M., Baghban, I., Eatemadi, O. ve Abedi, A. (2011). Personal and situational variables and career concerns: Predicting career adaptability in young adults. The Spanish Journal of Psychology, 14(1), 263271.

Zorver, C., ve Korkut-Owen, F. (2011). Kariyer uyumu ve iyimserliği ölçeğinin geliştirilmesi. XI. Ulusal Psikolojik Danışma ve Rehberlik Kongresinde Sözlü Bildiri, Ege Üniversitesi, İzmir.

\section{Kaynakça Bilgisi / Citation Information}

Taş, M.A.ve Özmen, M. (2019). Kişilik tipi ile kariyer ve akademik desteğin kariyer uyum yeteneklerine etkisi: Bir saha araştırması. OPUS-Uluslararası Toplum Araştırmaları Dergisi, 14(20), 333-370. DOI: 10.26466/opus.586662 